\title{
A p-tert-butylcalix[4]arene functionalised at its lower rim with ether-amide pendant arms acts as an inorganic-organic receptor: structural and photophysical properties of its lanthanide complexes $\dagger$
}

\author{
Flor de Maria Ramírez, ${ }^{a, b}$ Loïc Charbonnière, ${ }^{* c}$ Gilles Muller, ${ }^{a}$ Rosario Scopelliti ${ }^{a}$ \\ and Jean-Claude G. Bünzli *a \\ ${ }^{a}$ Institute of Inorganic and Analytical Chemistry, BCH, University of Lausanne, \\ CH-1015 Lausanne, Switzerland.E-mail: jean-claude.bunzli@icma.unil.ch \\ ${ }^{b}$ Instituto Nacional de Investigaciones Nucleares, Departamento de Química, \\ Km 36.5 Carretera México-Toluca, Salazar, Municipio de Ocoyoacac, C.P. 52045, \\ Edo. de México, México \\ ${ }^{c}$ Laboratoire de Chimie, Electronique et Photonique Moléculaires, UPRES-A 7008 au CNRS, \\ 25 Rue Becquerel, F-67087 Strasbourg, Cedex 02, France
}

Received 20th June 2001, Accepted 14th August 2001

First published as an Advance Article on the web 15th October 2001

\begin{abstract}
The new narrow-rim functionalised receptor 5,11,17,23-tetra-tert-butyl-25,26,27,28-tetrakis[2-(diethylcarbamoylmethoxy)ethoxy]calix[4]arene $\left(\mathrm{A}_{4} \mathrm{bL}^{4}\right)$ has been synthesised. NMR spectra show it to adopt a cone conformation in solution with a time-averaged $C_{4 \mathrm{v}}$ symmetry. $\mathrm{A}_{4} \mathrm{bL}^{4}$ reacts with trivalent lanthanide ions in acetonitrile to yield $1: 1$ complexes with $\log K_{1}$ in the range 8.6-9.6, as demonstrated by ES-MS, ${ }^{1} \mathrm{H}$ - and ${ }^{13} \mathrm{C}-\mathrm{NMR}$ data. Complexes with $\mathrm{Ln}$ $=\mathrm{Eu}, \mathrm{Gd}, \mathrm{Tb}$, and $\mathrm{Lu}$ have been isolated and the crystal structure of $\left[\mathrm{Lu}\left(\mathrm{A}_{4} \mathrm{bL}^{4}\right)\left(\mathrm{H}_{2} \mathrm{O}\right)\right]\left(\mathrm{CF}_{3} \mathrm{SO}_{3}\right)_{3} \cdot 2 \mathrm{Et}_{2} \mathrm{O}$ shows the metal ion encapsulated in the cavity formed by the four arms. $\mathrm{Lu}^{\mathrm{III}}$ is 9-co-ordinated, being bound to the four ether and four carbonyl functions and to a water molecule itself $\mathrm{H}$-bonded to the phenolic ether functions, which rigidifies the cavity formed by the pendant arms. Additionally, an ether molecule is inserted into the hydrophobic cavity defined by the aromatic rings. Both NMR ( $\mathrm{La}, \mathrm{Lu}$ ) and luminescence (Eu, Tb) data point to a fairly high local symmetry at the metal centre, while lifetime determinations are consistent with the co-ordination of an inner-sphere water molecule. The new ligand sensitises the luminescence of the $\mathrm{Tb}{ }^{\mathrm{III}}$ ion $\left(Q_{\mathrm{abs}}=5.8 \%\right.$ in acetonitrile, $\left.\tau_{\mathrm{F}}=1.42 \mathrm{~ms}\right)$ while the probable presence of a LMCT state severely limits such a process for $\mathrm{Eu}^{\mathrm{III}}: Q_{\mathrm{abs}}=2.0 \%, \tau_{\mathrm{F}}=0.73 \mathrm{~ms}$.
\end{abstract}

\section{Introduction}

Calixarene-based metalloreceptors are increasingly used in various fields of practical importance, ${ }^{1}$ e.g. the development of analytical luminescent sensors, ${ }^{2}$ of highly luminescent lanthanide-containing probes, ${ }^{3-5}$ of metal extraction and separation methods. ${ }^{6}$ Lately, calix-crowns, CMPO-substituted calixarenes (CMPO is $(N, N$-diisobutylcarbamoylmethyl)octylphosphine oxide) and calixarene amides have been shown to be efficient agents for the extraction of caesium, lanthanides and actinides from radioactive nuclear waste solutions, ${ }^{7,8}$ which explains the steady interest in these receptors. ${ }^{9}$

In our laboratory we have initially turned our attention to dimetallic lanthanide complexes with calix $[n]$ arenes $(n=5,8)$ for the purpose of studying energy transfer processes ${ }^{10}$ and, more recently, to the synthesis of calix $[n]$ arenes bearing phosphinoyl pendant arms. For instance, $p$-tert-butylcalix[4]arene symmetrically functionalised with phosphinoyl arms forms stable lanthanide complexes in anhydrous acetonitrile with two different metal-to-ligand ratios, $1: 1$ and $1: 2\left(\log \beta_{1}(\mathrm{La})=11.4\right.$ and $\log \beta_{2}(\mathrm{La})=19.6$, respectively). Moreover, in anhydrous $1: 1$ complexes, the lanthanide ion is complexed inside the cavity formed by the arms, while it lies in the upper part of it when solvated by water molecules. ${ }^{11}$ Calix[4]arenes substituted

$\uparrow$ Electronic supplementary information (ESI) available: ${ }^{1} \mathrm{H}$ - and ${ }^{13} \mathrm{C}$ NMR spectra of $\mathrm{A}_{4} \mathrm{bL}^{4}$ and its $\mathrm{Lu}^{\mathrm{III}}$ complex, excitation spectrum of the Eu ${ }^{\text {III }}$ complex. See http://www.rsc.org/suppdata/dt/b1/b105513p/ at the narrower rim by four alkylamide functions feature a highly flexible non-preorganised pseudo cavity, but retain the cone conformation favourable to host-guest chemistry. They are therefore good complexation agents for alkali, alkaline earth and f-element cations. ${ }^{12-16}$ However, to our knowledge, relatively little work has been done on lanthanide complexes with calixarenes symmetrically grafted with pendant arms bearing acetamide derivatives, besides the initial work on p-tert-butylcalix[4]arene tetra-amide $\left(\mathrm{L}^{0}\right) .{ }^{16-18}$ Our aim here is to design a predisposed host molecule bearing relatively long arms able to form a protective induced cavity upon complexation. We report the synthesis and characterisation of a new p-tertbutylcalix[4]arene functionalised at the narrower rim by four ether-amide arms, 5,11,17,23-tetra-tert-butyl-25,26,27,28-tetrakis[2-(diethylcarbamoylmethoxy)ethoxy]calix[4]arene $\left(\mathrm{A}_{4} \mathrm{bL}^{4}\right.$, Scheme 1) as well as of its complexes with $\mathrm{Ln}^{\mathrm{III}}$ ions. Structural and photophysical data are presented and discussed.

\section{Results and discussion}

\section{Synthesis and characterisation of $\mathrm{A}_{4} \mathrm{bL}^{4}$}

The branched calix[4]arene $\mathrm{A}_{4} \mathrm{bL}^{4}$ was obtained in four steps from the commercially available diglycolic anhydride $\mathbf{1}$ and p-tert-butylcalix[4]arene. First, diethylcarbamoylmethoxy acetic acid $\mathbf{2}$ was isolated as an oily liquid in $81 \%$ yield upon reaction of 1 with an excess of diethylamine in refluxing $\mathrm{CH}_{2} \mathrm{Cl}_{2}$ 


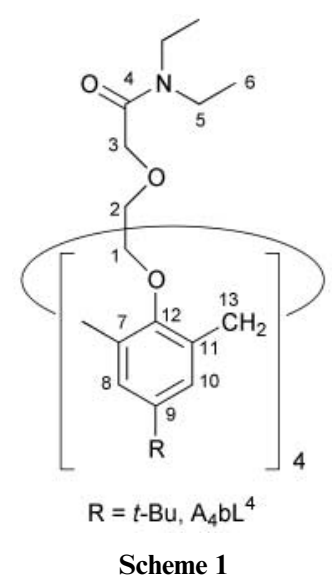<smiles>O=C1COCC(=O)O1</smiles>

1<smiles>CCNCC[C@H]([18OH])CC</smiles>

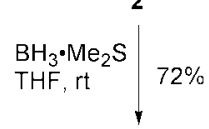<smiles>CCN(CC)C(=O)COCCO</smiles>
4

3

Scheme 2

(Scheme 2). Selective reduction of the acid function with $\mathrm{BH}_{3}$ $\mathrm{Me}_{2} \mathrm{~S}$ in THF at room temperature afforded $N, N$-diethyl-2(2-hydroxyethoxy)acetamide 3 in $72 \%$ yield. Bromination of the hydroxy group was achieved in refluxing acetonitrile using $\mathrm{SOBr}_{2}$ in the presence of $\mathrm{Et}_{3} \mathrm{~N}$ as a base. After purification, 4 was obtained in $56 \%$ yield. Different attempts to obtain 4 using other solvents such as $\mathrm{CH}_{2} \mathrm{Cl}_{2}$ or $\mathrm{C}_{2} \mathrm{H}_{4} \mathrm{Cl}_{2}$ proved to be far less efficient and, in the latter case, the major species was the chlorinated compound. The longer reaction times required in these conditions may lead to thermal decomposition of the solvent with subsequent release of chloride which competes efficiently with bromide in the nucleophilic substitution at the carbon atom.

Ligand $\mathrm{A}_{4} \mathrm{bL}^{4}$ was obtained in $50 \%$ yield via Williamson reactions by refluxing the tetrasodium derivative of $p$-tertbutylcalix[4]arene and excess $\mathbf{4}$ in toluene. This procedure demonstrates that the tetrasodium derivative can be formed even in a non polar solvent, provided adequate experimental conditions are used: heating, strong stirring, and nitrogen atmosphere to avoid oxidation of the phenoxide groups. The elemental analysis indicates that the isolated product is not solvated. The IR spectrum shows an intense band at $1651 \mathrm{~cm}^{-1}$ typical of the carbonyl groups in a substituted amide $\left(1646 \mathrm{~cm}^{-1}\right.$ in 4); the aliphatic ether groups appear at $1123 \mathrm{~cm}^{-1}\left(1119 \mathrm{~cm}^{-1}\right.$ in 4) while medium bands at 1203 and $1053 \mathrm{~cm}^{-1}$ are typical of the phenoxide groups. Calixarene $\mathrm{A}_{4} \mathrm{bL}^{4}$ is soluble in $\mathrm{CH}_{2} \mathrm{Cl}_{2}, \mathrm{CHCl}_{3}, \mathrm{CH}_{3} \mathrm{CN}$, toluene, methanol and ethanol. It can be re-crystallised from various solvent mixtures such as toluene-acetonitrile, diisopropyl ether-acetonitrile, and diethyl ether-acetonitrile.

The ${ }^{1} \mathrm{H}-\mathrm{NMR}$ spectrum of $\mathrm{A}_{4} \mathrm{bL}^{4}$ in $\mathrm{CD}_{3} \mathrm{CN}$ (Figs. 1 and $\mathrm{S} 1$, ESI) shows the ligand adopting a highly symmetrical conformation, $c f$. the presence of a single signal for the aromatic protons. This excludes the partial cone or 1,2-alternate conformations for the calixarene. The presence of an $\mathrm{AB}$ spin system $\left(4.53 \mathrm{ppm},{ }^{2} J=12.0 \mathrm{~Hz}\right.$ for $\mathrm{H}^{13}$ ax and $3.24 \mathrm{ppm},{ }^{3} \mathrm{~J}=$

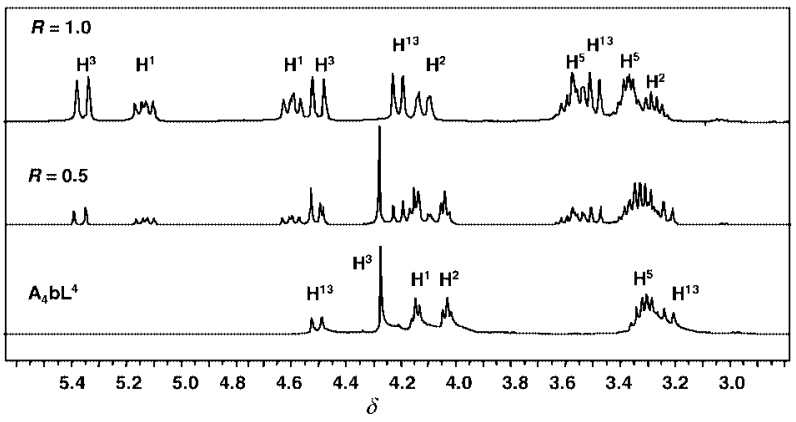

Fig. 1 Part of the ${ }^{1} \mathrm{H}-\mathrm{NMR}$ spectra of the ligand $\mathrm{A}_{4} \mathrm{bL}^{4}, 10^{-3} \mathrm{M}$ in $\mathrm{CD}_{3} \mathrm{CN}$, and of solutions containing $\mathrm{Lu}\left(\mathrm{CF}_{3} \mathrm{SO}_{3}\right)_{3}, R=[\mathrm{Lu}]_{\mathrm{t}}\left[\mathrm{A}_{4} \mathrm{bL}^{4}\right]_{\mathrm{t}}$, at $298 \mathrm{~K}$.

$12.5 \mathrm{~Hz}$ for $\mathrm{H}^{13}{ }_{\text {eq }}$ ) for the methylenic protons of the macrocyclic platform, together with a large $\Delta \delta$ value of $1.29 \mathrm{ppm}$ between the two signals unambiguously points to a pure cone conformation with a time-averaged $C_{4 \mathrm{v}}$ symmetry on the NMR time scale, both in acetonitrile and chloroform solutions. It has been reported $^{1,19}$ that the cone conformation of calix[4]arene often appears to be favoured by a template effect from the sodium ion present in bases, such as $\mathrm{Na}_{2} \mathrm{CO}_{3}, \mathrm{Na}$ or $\mathrm{NaH}$, used for substitution at the lower rim. As a result of the hindered rotation around the $\mathrm{C}(\mathrm{O})-\mathrm{N}$ bond, ${ }^{20}$ the ethyl groups appear as two distinct $\mathrm{A}_{2} \mathrm{X}_{3}$ spin systems. The partial superimposition of the two methylene quadruplets gives a multiplet at $3.32 \mathrm{ppm}$ while two triplets are observed at 1.08 and $1.13 \mathrm{ppm}$ for the methyl groups. If the singlet at $4.27 \mathrm{ppm}$ can unequivocally be assigned to $\mathrm{H}^{3}$, the assignment of the two remaining triplets at 4.04 and 4.15 ppm to protons $\mathrm{H}^{1}$ and $\mathrm{H}^{2}$ is more difficult. Unfortunately, 2D-COSY and NOESY experiments do not yield further information. However, based on the electron acceptor and donor properties of $\mathrm{A}_{4} \mathrm{bL}^{4}$, the spectra obtained for $\mathbf{4}$, as well as information reported in the literature, ${ }^{21-23}$ it seems reasonable to assume that proton $\mathrm{H}^{1}$ gives rise to the signal centred at 4.15 ppm. ${ }^{13} \mathrm{C}-\left\{{ }^{1} \mathrm{H}\right\}$ NMR spectra in $\mathrm{CDCl}_{3}$ and $\mathrm{CD}_{3} \mathrm{CN}$ confirm the tetragonal symmetry adopted by the ligand in solution (Fig. S2, ESI). Only four signals are observed for the aromatic carbon atoms at $126.3\left(\mathrm{C}^{8}, \mathrm{C}^{10}\right), 135.1\left(\mathrm{C}^{7}, \mathrm{C}^{11}\right), 146.5\left(\mathrm{C}^{9}\right)$, and $154.5\left(\mathrm{C}^{12}\right) \mathrm{ppm}$ in $\mathrm{CD}_{3} \mathrm{CN}$, indicating the presence of two dihedral and two vertical planes of symmetry thus confirming the $C_{4 \mathrm{v}}$ averaged symmetry for the free ligand in solution.

\section{Complexation of $\mathrm{A}_{4} \mathrm{bL}^{4}$ with lanthanide ions in anhydrous acetonitrile}

To gain information about the interaction between lanthanide ions and ligand $\mathrm{A}_{4} \mathrm{bL}^{4}$, solutions of the latter (typically $1 \times$ $\left.10^{-3} \mathrm{M}\right)$ were titrated by solutions of $\mathrm{Ln}\left(\mathrm{CF}_{3} \mathrm{SO}_{3}\right)_{3} \cdot x \mathrm{H}_{2} \mathrm{O}$ (typically $10^{-2}-10^{-3} \mathrm{M}, \mathrm{Ln}=\mathrm{La}, \mathrm{Eu}, \mathrm{Tb}, \mathrm{Lu}$ ) for ratios $R=$ $\left.\left[\mathrm{Ln}^{\mathrm{III}}\right]_{\mathrm{t}} /\left[\mathrm{A}_{4} \mathrm{bL}\right]_{\mathrm{t}}\right]_{\mathrm{t}}$ varying from 0 to 3 . In a first set of experiments, and to establish the speciation, the titrations with $\mathrm{Ln}=\mathrm{La}, \mathrm{Tb}$ and Lu were monitored by ES-MS spectroscopy. In all cases, complexed species with a stoichiometric ratio of $1: 1$ were observed. Three important species, namely $\left[\operatorname{Ln}\left(\mathrm{A}_{4} \mathrm{bL}^{4}\right)\right.$ $\left.\left(\mathrm{H}_{2} \mathrm{O}\right)\right]^{3+},\left[\mathrm{Ln}\left(\mathrm{CF}_{3} \mathrm{SO}_{3}\right)\left(\mathrm{A}_{4} \mathrm{bL}^{4}\right)\right]^{2+}$, and $\left[\mathrm{Ln}(\mathrm{OH})\left(\mathrm{A}_{4} \mathrm{bL}^{4}\right)\left(\mathrm{CH}_{3}-\right.\right.$ $\mathrm{CN}]^{2+}$, were observed (Table 1). It is quite probable that the hydroxy species is formed by hydrolysis in the capillary during the analysis $\left(T=200{ }^{\circ} \mathrm{C}\right)$. No free ligand was detected in any of the solutions with $R>1$, pointing to the formation of stable $1: 1$ complexes.

The speciation was further confirmed by monitoring the titration by ${ }^{1} \mathrm{H}-\mathrm{NMR}$. In the case of $\mathrm{Lu}{ }^{\mathrm{III}}$ (see Fig. 1), a single new species is formed, whatever the amount of added metal ion is. For $R$ values smaller than 1 , the free ligand and the complexed $1: 1$ species co-exist in solution, with no evidence of a kinetic exchange process on the NMR time scale, nor of the formation of a species with $1: 2$ metal : ligand ratio. For $R \geq 1$, 
Table 1 Species observed by ES-MS during the titration of $\mathrm{A}_{4} \mathrm{bL}^{4}, 1 \times 10^{-3} \mathrm{M}$, by $\mathrm{Ln}\left(\mathrm{CF}_{3} \mathrm{SO}_{3}\right)_{3} \cdot x \mathrm{H}_{2} \mathrm{O}, 10^{-2}-10^{-3} \mathrm{M}$

\begin{tabular}{|c|c|c|c|c|c|c|c|c|c|}
\hline \multirow[b]{2}{*}{ Ln } & \multicolumn{3}{|c|}{$\underline{\left[\operatorname{Ln}\left(\mathrm{A}_{4} \mathrm{bL}^{4}\right)\left(\mathrm{H}_{2} \mathrm{O}\right)\right]^{3+}}$} & \multicolumn{3}{|c|}{$\left[\mathrm{Ln}\left(\mathrm{CF}_{3} \mathrm{SO}_{3}\right)\left(\mathrm{A}_{4} \mathrm{bL}^{4}\right)\right]^{2+}$} & \multicolumn{3}{|c|}{$\left[\mathrm{Ln}(\mathrm{OH})\left(\mathrm{A}_{4} \mathrm{bL}^{4}\right)\left(\mathrm{CH}_{3} \mathrm{CN}\right)\right]^{2+}$} \\
\hline & $I_{\text {rel }}$ & $m / z(\exp )$ & $m / z($ calc $)$ & $I_{\text {rel }}$ & $m / z(\exp )$ & $\mathrm{m} / \mathrm{z}$ (calc) & $I_{\text {rel }}$ & $m / z(\exp )$ & $\mathrm{m} / \mathrm{z}(\mathrm{calc})$ \\
\hline $\mathrm{La}$ & 100 & 478.40 & 478.23 & 20 & 783.32 & 782.88 & 40 & 737.86 & 737.37 \\
\hline $\mathrm{Tb}$ & 100 & 484.85 & 484.91 & 30 & 792.85 & 792.89 & 24 & 747.89 & 747.38 \\
\hline $\mathrm{Lu}$ & 100 & 490.31 & 490.25 & 80 & 800.89 & 800.91 & 20 & 755.83 & 755.40 \\
\hline
\end{tabular}

Table 2 Chemical shifts (ppm) of the ligand $\mathrm{A}_{4} \mathrm{bL}^{4}$ and its $1: 1$ complexes with $\mathrm{La}$, Eu and $\mathrm{Lu}, 10^{-3} \mathrm{M}$, in anhydrous $\mathrm{CD}_{3} \mathrm{CN}$ at $298 \mathrm{~K}^{a}$

\begin{tabular}{|c|c|c|c|c|c|c|c|c|}
\hline & $\mathrm{H}^{1}$ & $\mathrm{H}^{2}$ & $\mathrm{H}^{3}$ & $\mathrm{H}^{5}$ & $\mathrm{H}^{6}$ & $\mathrm{H}^{8,10}$ & $\mathrm{H}^{13}$ & $t$-Bu \\
\hline $\mathrm{A}_{4} \mathrm{bL}^{4}$ & $4.13-4.16$ & $4.02-4.05$ & $4.27(\mathrm{~s})$ & $3.26-3.36$ & $1.06-1.14$ & 7.07 & $\begin{array}{l}4.49-4.52 \\
3.20-3.24\end{array}$ & 1.16 \\
\hline $\mathrm{La}$ & $\begin{array}{l}4.39 \text { (br) } \\
4.94 \text { (br) }\end{array}$ & $4.20-4.23$ & $4.32,5.23$ (br) & $\begin{array}{l}3.34-3.49 \\
3.11-3.17\end{array}$ & $\begin{array}{l}1.26-1.30(\mathrm{t}) \\
1.15-1.19(\mathrm{t})\end{array}$ & $7.38,7.55$ & $3.43-3.48$ & $\begin{array}{l}1.25 \\
1.28\end{array}$ \\
\hline $\mathrm{Eu}$ & $2.45,4.55$ & $-1.2,4.0$ & $-3.8,3.0$ & $\begin{array}{l}2.1-2.35 \\
4.0-4.3\end{array}$ & $0.57,1.95$ & $7.93,7.98$ & $4.1,5.7$ & 1.5 \\
\hline $\mathrm{Lu}$ & $\begin{array}{l}5.09-5.16 \\
4.55-4.61\end{array}$ & $\begin{array}{l}4.08-4.12 \\
3.23-3.27\end{array}$ & $\begin{array}{l}5.33,5.37(\mathrm{~d}) \\
4.47,4.51(\mathrm{~d})\end{array}$ & $\begin{array}{l}3.52-3.62 \\
3.32-3.39\end{array}$ & $\begin{array}{l}1.27-1.31(\mathrm{t}) \\
1.16-1.20(\mathrm{t})\end{array}$ & $7.35-7.40$ & $\begin{array}{l}3.46,3.50(\mathrm{~d}) \\
4.18,4.21(\mathrm{~d})\end{array}$ & $\begin{array}{l}1.24 \\
1.24\end{array}$ \\
\hline
\end{tabular}

only signals from the $1: 1$ complexes are present (Table 2). Stability constants were estimated using the MINEQL ${ }^{+}$program, ${ }^{24}$ leading to the following values: $\log K_{1}=9.6 \pm 0.1$ and $8.6 \pm 0.6$ for La and Lu, respectively $( \pm 2 \sigma)$.

$$
\mathrm{A}_{4} \mathrm{bL}^{4}+\mathrm{Ln}^{3+} \longrightarrow\left[\operatorname{Ln}\left(\mathrm{A}_{4} \mathrm{bL}^{4}\right)\right]^{3+} \log K_{1}
$$

For a $1: 1$ lanthanum complex with $p$-tert-butylcalix[4]arene fitted with phosphinoyl pendant arms, a somewhat $\operatorname{larger} \log K_{1}$ value of 11.4 has been reported, based on spectrophotometric titrations, ${ }^{11}$ in line with the larger co-ordination strength of phosphinoyl groups compared to amide functions.

\section{Solution structure of the $1: 1$ complexes in anhydrous acetonitrile}

The NMR spectra of the complexes display important shifts and changes of multiplicity compared to the free ligand spectrum, as demonstrated by the $\mathrm{Lu}^{\mathrm{III}}$ spectrum (Fig. 1, Table 2, Fig. S3, ESI). The most striking feature is the splitting of the signals arising from protons related by the dihedral and vertical planes of symmetry in the free ligand. The degeneracy of the $\mathrm{H}^{1}, \mathrm{H}^{2}$ and $\mathrm{H}^{3}$ protons is lifted upon complexation, which gives rise to two signals for each methylenic set of protons. Similarly, the aromatic singlet observed at $7.06 \mathrm{ppm}$ for the free ligand now appears as two doublets at 7.37 and $7.42 \mathrm{ppm}$ with ${ }^{4} \mathrm{~J}$ values of $2.5 \mathrm{~Hz}$. This reflects a lowering of the symmetry from $C_{4 \mathrm{v}}$ to $C_{4}$, which can be understood as resulting from the chirality induced by the wrapping of the arms around the metal ion. The largest difference observed between the chemical shifts of free and complexed ligand occurs for $\mathrm{H}^{3}$, which indicates that the metal ion is co-ordinated by both the amide and aliphatic ether functions (a fact confirmed in the solid state by IR data, see below). Another interesting point is the decrease in the difference in chemical shifts between $\mathrm{H}^{13}$ ax and $\mathrm{H}^{13}$ eq, which drops from $\Delta \delta=1.29 \mathrm{ppm}$ in the free ligand to $0.72 \mathrm{ppm}$ in the complex. Such a decrease has been previously ascribed to changes in the conformation from cone toward flattened cone, with $\Delta \delta=0 \mathrm{ppm}$ in the extreme case of 1,3 -alternate conformation. 25

Finally, a singlet at $7.05 \mathrm{ppm}$ which integrates for two protons appears in the spectrum of the $\mathrm{Lu}^{\mathrm{III}}$ complex and despite its large shift is assigned to a co-ordinated water molecule. 2DCOSY and NOESY experiments do not reveal any scalar nor dipolar interaction with other parts of the molecule nor with the peak at $2.56 \mathrm{ppm}$ which corresponds to free water. Upon addition of deuterated water, the signal at $7.05 \mathrm{ppm}$ disappears as a result of an exchange process with $\mathrm{D}_{2} \mathrm{O}$. The large shift with respect to the free water signal $(\Delta \delta=4.44 \mathrm{ppm})$ and the slow exchange rate on the NMR time scale point to the water molecule being co-ordinated inside the cavity defined by the ether functions of the arms and the phenoxide functions of the calixarene. The addition of $\mathrm{D}_{2} \mathrm{O}$ also induces other changes (Fig. S3, ESI): the two aromatic signals coalesce into a single one while all methylenic peaks, except those of the macrocyclic core, are broadened. The introduction of (deuterated) water into the solution is expected to provide a competitive pathway for complexation to the $\mathrm{Lu}^{\mathrm{III}}$ cation, by formation of hydrated species. The equilibrium between hydrated species and [Ln$\left.\left(\mathrm{A}_{4} \mathrm{bL}^{4}\right)\left(\mathrm{H}_{2} \mathrm{O}\right)\right]^{3+}$ is then shifted toward the hydrated form, while remaining largely in favour of the complexed species, as evidenced by the NMR spectrum.

On the basis of the ${ }^{1} \mathrm{H}-\mathrm{NMR}$ data in anhydrous acetonitrile and the X-ray crystal structure (vide infra), we can infer that complexation of the metal ion induces a wrapping of the chelating arms around the metal centre in a clockwise ( $\Delta$ isomer) or anticlockwise ( $\Lambda$ isomer) sense. If we suppose that the interconversion process which leads to the exchange between the $\Delta \leftrightarrow \Lambda$ forms of the complex is governed by a transition state in which part (if not all) ${ }^{26}$ of the chelating arms are displaced by water molecules, this process should be favoured by the addition of water and should lead to the coalescence of the aromatic signals. This is precisely what we observe with the aromatic signals, which coalesce, pointing to an exchange process between $\mathrm{H}^{8}$ and $\mathrm{H}^{10}$. The larger $\Delta \delta$ values for the other sets of methylenic protons do not allow coalescence, so that the corresponding signals are simply broadened. As the AB pattern corresponding to $\mathrm{H}^{13}$ is clearly unchanged in the presence of added water, the cone conformation is certainly retained during these exchange processes.

The ${ }^{13} \mathrm{C}$-NMR spectrum of the $\mathrm{Lu}{ }^{\mathrm{III}}$ complex confirms the symmetry deduced from the ${ }^{1} \mathrm{H}$ spectrum and displays sizeable shifts for the aromatic and carbonyl carbon atoms of the complex compared to the free ligand: $\Delta \delta\left(=\delta_{\text {complex }}-\delta_{\text {ligand }}\right)=0.6$ and $0.2 \mathrm{ppm}\left(\mathrm{C}^{7,11}\right), 1.4$ and $0.3 \mathrm{ppm}\left(\mathrm{C}^{8,10}\right), 2.9 \mathrm{ppm}\left(\mathrm{C}^{9}\right)$, $-1.6 \mathrm{ppm}\left(\mathrm{C}^{12}\right),-2.9 \mathrm{ppm}\left(\mathrm{C}^{4}\right)$ and $-0.6 \mathrm{ppm}\left(\mathrm{C}^{13}\right){ }^{22}$

Generally speaking, the ${ }^{1} \mathrm{H}-\mathrm{NMR}$ spectra of the $\mathrm{Eu}^{\mathrm{III}}$ and $\mathrm{Tb}^{\mathrm{III}} 1: 1$ complexes confirm the high symmetry conformation deduced for the $\mathrm{Lu}^{\mathrm{III}}$ compound. For $\mathrm{Eu}^{\mathrm{III}}$, a broad signal at $6.3 \mathrm{ppm}$ is associated with two molecules of co-ordinated water, possibly undergoing an exchange mechanism. A quasi-doublet at 5.75 and a doublet at $4.1 \mathrm{ppm}\left({ }^{2} J=13 \mathrm{~Hz}\right)$ are assigned to the bridging methylene groups $\mathrm{H}^{13}$, while the peaks at -3.9 and 


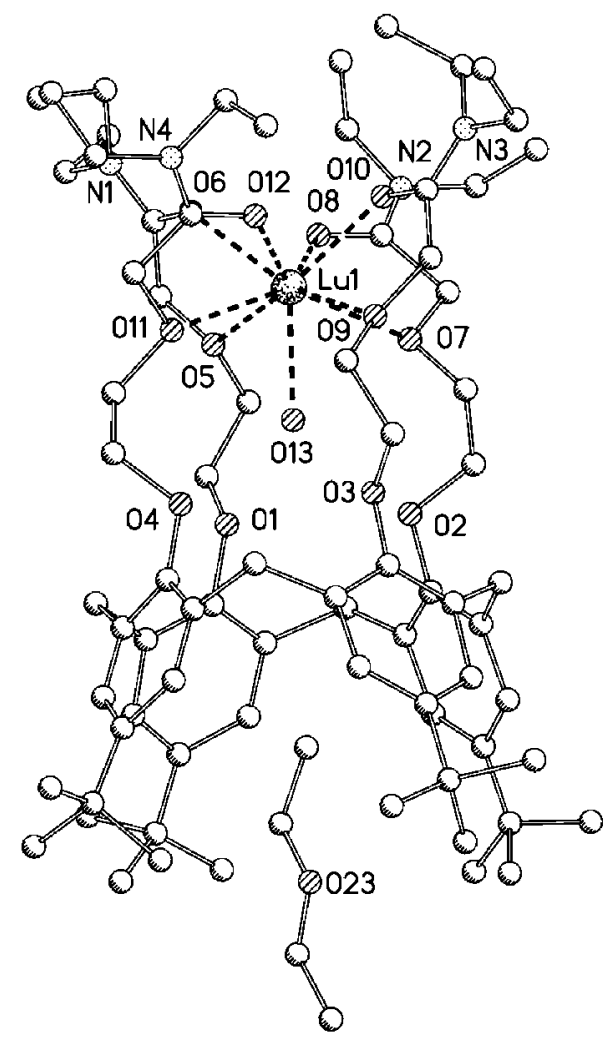

Fig. 2 Molecular structure of $\left[\mathrm{Lu}\left(\mathrm{A}_{4} \mathrm{bL}^{4}\right)\left(\mathrm{H}_{2} \mathrm{O}\right)\right]\left(\mathrm{CF}_{3} \mathrm{SO}_{3}\right)_{3} \cdot 2 \mathrm{Et}_{2} \mathrm{O}$

$3.0 \mathrm{ppm}$ are attributed to the $-\mathrm{O}-\mathrm{C}\left(\mathrm{H}^{3}\right)_{2}-$ methylene groups. The large shifts experienced by these protons again point to the co-ordination of the four ether functions to the metal ion. The spectrum of the $\mathrm{Tb}^{\mathrm{III}}$ complex displays fairly broad singlet signals ranging from +27 to $-40 \mathrm{ppm}$, which are difficult to assign.

\section{Isolated complexes and crystal structure of the $\mathrm{Lu}^{\mathrm{III}}$ complex}

The $1: 1$ complexes of $\mathrm{Eu}^{\mathrm{III}}, \mathrm{Gd}^{\mathrm{III}}, \mathrm{Tb}^{\mathrm{III}}$ and $\mathrm{Lu}^{\mathrm{III}}$ have been isolated from equimolar mixtures of $\mathrm{A}_{4} \mathrm{bL}^{4}$ and the corresponding triflate salts. According to the elemental analyses the general formula for the complexes is $\mathrm{Ln}\left(\mathrm{A}_{4} \mathrm{bL}^{4}\right)(\mathrm{OTf})_{3} \cdot n \mathrm{H}_{2} \mathrm{O}(n=3$ for $\mathrm{Eu}$ and 6 for $\mathrm{Tb}, \mathrm{Gd}$ and $\mathrm{Lu}$ ). A closer examination of the changes in the IR spectra upon complexation gives important information. The $v_{\mathrm{C}-\mathrm{O}}$ vibration is shifted to lower energy by $30-35 \mathrm{~cm}^{-1}$ with respect to the ligand, pointing to a strong metal-to-ligand interaction with the carbonyl groups. Moreover, the intensity of the band arising from the aliphatic ether $\left(-\mathrm{OCH}_{2}-\mathrm{CON}\right)$ is strongly reduced pointing to co-ordination of these ether moieties to the metal ion, while the two aromatic ether vibrations are only slightly shifted to lower energy, the one at $1264 \mathrm{~cm}^{-1}$ being more intense than in the free ligand, which indicates that these functions are implied in some kind of interaction. The sharp band at $1480 \mathrm{~cm}^{-1}$ corresponding to the $\left(\mathrm{CH}_{n}\right)$ vibrations is split into two components with $\Delta v=$ $21 \mathrm{~cm}^{-1}$. Two strong bands at 1031 and $639 \mathrm{~cm}^{-1}$ are also seen, which have been assigned to the $v_{\mathrm{s}}\left(\mathrm{SO}_{2}\right)$ and $\delta_{\text {as }}\left(\mathrm{SO}_{3}\right)$ modes, respectively, of co-ordinated triflate in anhydrous lanthanide salts ${ }^{27}$ and in lanthanide complexes formed with a chiral benzimidazole pyridine derivative. ${ }^{28}$ Finally, bands at 574 and $517 \mathrm{~cm}^{-1}$ are indicative of the presence of co-ordinated water molecule(s). ${ }^{29}$

Crystals suitable for X-ray diffraction analysis were obtained for the $\mathrm{Lu}^{\mathrm{III}}$ complex, which turned out to have the formula $\left[\mathrm{Lu}\left(\mathrm{A}_{4} \mathrm{bL}^{4}\right)\left(\mathrm{H}_{2} \mathrm{O}\right)\right]\left(\mathrm{CF}_{3} \mathrm{SO}_{3}\right)_{3} \cdot 2 \mathrm{Et}_{2} \mathrm{O}$. The molecular structure could be solved and is displayed on Fig. 2, along with a partial atom-numbering scheme, while relevant bond lengths and angles are listed in Table 3. The $\mathrm{Lu}^{\mathrm{III}}$ ion is 9-co-ordinate,
Table 3 Bond lengths $(\AA)$ and angles $\left(^{\circ}\right)$ for the co-ordination polyhedron in $\left[\mathrm{Lu}\left(\mathrm{A}_{4} \mathrm{bL}^{4}\right)\left(\mathrm{H}_{2} \mathrm{O}\right)\right]\left(\mathrm{CF}_{3} \mathrm{SO}_{3}\right)_{3} \cdot 2 \mathrm{Et}_{2} \mathrm{O}$. Standard deviations are given in parentheses

\begin{tabular}{lrlr}
\hline $\mathrm{Lu}(1)-\mathrm{O}(6)$ & $2.237(8)$ & $\mathrm{Lu}(1)-\mathrm{O}(7)$ & $2.500(9)$ \\
$\mathrm{Lu}(1)-\mathrm{O}(8)$ & $2.281(13)$ & $\mathrm{Lu}(1)-\mathrm{O}(9)$ & $2.430(8)$ \\
$\mathrm{Lu}(1)-\mathrm{O}(10)$ & $2.271(8)$ & $\mathrm{Lu}(1)-\mathrm{O}(11)$ & $2.481(10)$ \\
$\mathrm{Lu}(1)-\mathrm{O}(12)$ & $2.288(10)$ & $\mathrm{Lu}(1)-\mathrm{O}(13)$ & $2.311(9)$ \\
$\mathrm{Lu}(1)-\mathrm{O}(5)$ & $2.408(8)$ & & \\
& & & \\
$\mathrm{O}(5)-\mathrm{Lu}(1)-\mathrm{O}(6)$ & $68.0(3)$ & $\mathrm{O}(9)-\mathrm{Lu}(1)-\mathrm{O}(8)$ & $129.3(4)$ \\
$\mathrm{O}(5)-\mathrm{Lu}(1)-\mathrm{O}(7)$ & $90.3(3)$ & $\mathrm{O}(9)-\mathrm{Lu}(1)-\mathrm{O}(10)$ & $66.8(3)$ \\
$\mathrm{O}(5)-\mathrm{Lu}(1)-\mathrm{O}(8)$ & $68.5(3)$ & $\mathrm{O}(9)-\mathrm{Lu}(1)-\mathrm{O}(12)$ & $69.4(3)$ \\
$\mathrm{O}(5)-\mathrm{Lu}(1)-\mathrm{O}(10)$ & $140.3(3)$ & $\mathrm{O}(10)-\mathrm{Lu}(1)-\mathrm{O}(12)$ & $72.9(3)$ \\
$\mathrm{O}(5)-\mathrm{Lu}(1)-\mathrm{O}(12)$ & $131.7(3)$ & $\mathrm{O}(11)-\mathrm{Lu}(1)-\mathrm{O}(6)$ & $71.9(3)$ \\
$\mathrm{O}(6)-\mathrm{Lu}(1)-\mathrm{O}(8)$ & $71.5(4)$ & $\mathrm{O}(11)-\mathrm{Lu}(1)-\mathrm{O}(8)$ & $137.1(4)$ \\
$\mathrm{O}(7)-\mathrm{Lu}(1)-\mathrm{O}(6)$ & $136.8(4)$ & $\mathrm{O}(11)-\mathrm{Lu}(1)-\mathrm{O}(9)$ & $93.5(3)$ \\
$\mathrm{O}(7)-\mathrm{Lu}(1)-\mathrm{O}(8)$ & $65.8(3)$ & $\mathrm{O}(11)-\mathrm{Lu}(1)-\mathrm{O}(10)$ & $136.5(3)$ \\
$\mathrm{O}(7)-\mathrm{Lu}(1)-\mathrm{O}(10)$ & $73.0(3)$ & $\mathrm{O}(11)-\mathrm{Lu}(1)-\mathrm{O}(12)$ & $63.7(3)$ \\
$\mathrm{O}(7)-\mathrm{Lu}(1)-\mathrm{O}(11)$ & $141.4(3)$ & $\mathrm{O}(12)-\mathrm{Lu}(1)-\mathrm{O}(6)$ & $73.1(3)$ \\
$\mathrm{O}(7)-\mathrm{Lu}(1)-\mathrm{O}(12)$ & $138.0(3)$ & $\mathrm{O}(13)-\mathrm{Lu}(1)-\mathrm{O}(5)$ & $72.1(3)$ \\
$\mathrm{O}(8)-\mathrm{Lu}(1)-\mathrm{O}(10)$ & $71.7(3)$ & $\mathrm{O}(13)-\mathrm{Lu}(1)-\mathrm{O}(7)$ & $70.7(3)$ \\
$\mathrm{O}(9)-\mathrm{Lu}(1)-\mathrm{O}(5)$ & $144.1(3)$ & $\mathrm{O}(13)-\mathrm{Lu}(1)-\mathrm{O}(9)$ & $72.1(3)$ \\
$\mathrm{O}(9)-\mathrm{Lu}(1)-\mathrm{O}(6)$ & $142.4(3)$ & $\mathrm{O}(13)-\mathrm{Lu}(1)-\mathrm{O}(11)$ & $70.6(3)$ \\
\hline
\end{tabular}

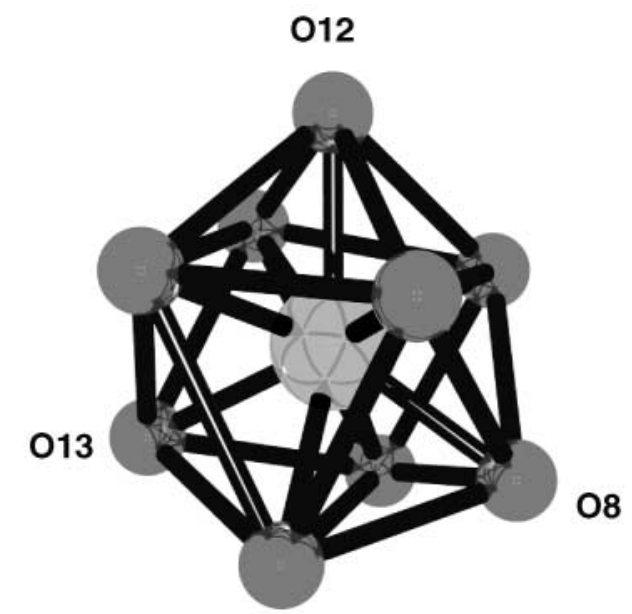

Fig. 3 Co-ordination polyhedron around $\mathrm{Lu}{ }^{\mathrm{III}}$ in $\left[\mathrm{Lu}\left(\mathrm{A}_{4} \mathrm{bL}^{4}\right)\right.$ $\left.\left(\mathrm{H}_{2} \mathrm{O}\right)\right]\left(\mathrm{CF}_{3} \mathrm{SO}_{3}\right)_{3} \cdot 2 \mathrm{Et}_{2} \mathrm{O}$ (capping atoms are indicated).

being bound to the four amide oxygen atoms, to the four ether oxygen atoms of the pendant arms and to one water molecule located inside the cavity formed by the four phenolic ether groups and the four ether functions. The $\mathrm{Lu}-\mathrm{O}$ (amide) bond length ranges between 2.237(8) and 2.288(10) $\AA$ with a mean distance of 2.269(10) $\AA$, that is, on average, $0.186 \AA$ shorter than the Lu-O(ether) distance (2.455(9), 2.408(8)-2.500(9) $\AA$ ), while the $\mathrm{Lu}-\mathrm{O}(\mathrm{w})$ bond length amounts to $2.311(9) \AA$. The overall Lu-O mean distance is equal to 2.356(9) $\AA$, which translates into an ionic radius of $1.05 \AA$ according to Shannon's definition (and with $r(\mathrm{O})=1.31 \AA$ ), that is, close to the expected value of $1.03 \AA^{30}$ The co-ordination polyhedron can be described as a distorted tricapped trigonal prism (Fig. 3), a fairly usual geometry for 9-co-ordinate $\mathrm{Ln}^{\mathrm{III}}$ ions. ${ }^{31}$ Atoms $\mathrm{O}(8)$, $\mathrm{O}(12)$ and $\mathrm{O}(13)$, with mean $\mathrm{Lu}-\mathrm{O}$ distance of 2.293(11) $\AA$ (2.281(13)-2.311(9) $\AA$ ), are capping the three square planes defined by (i) $\mathrm{O}(5), \mathrm{O}(7), \mathrm{O}(9), \mathrm{O}(11)$, (ii) $\mathrm{O}(5), \mathrm{O}(6), \mathrm{O}(7)$, $\mathrm{O}(10)$ and (iii) $\mathrm{O}(6), \mathrm{O}(9), \mathrm{O}(10), \mathrm{O}(11)$ for which the corner angles are in the ranges $87-92^{\circ}, 88-92^{\circ}$, and $87-93^{\circ}$, respectively. The prism is defined by the two triangles $\mathrm{O}(5), \mathrm{O}(6), \mathrm{O}(11)$ and $\mathrm{O}(7), \mathrm{O}(9), \mathrm{O}(10)$, the fold angles between them being $3^{\circ}$ while the corner angles span the ranges $53-70^{\circ}$ and $53-67^{\circ}$, respectively.

The calixarene adopts a cone conformation with cone angles between opposite phenyl rings of 52.5(7) and $42.6(8)^{\circ}$. The four arms organise themselves so that the four O(ether) atoms are co-planar while the four $\mathrm{O}$ (amide) atoms define a puckered 


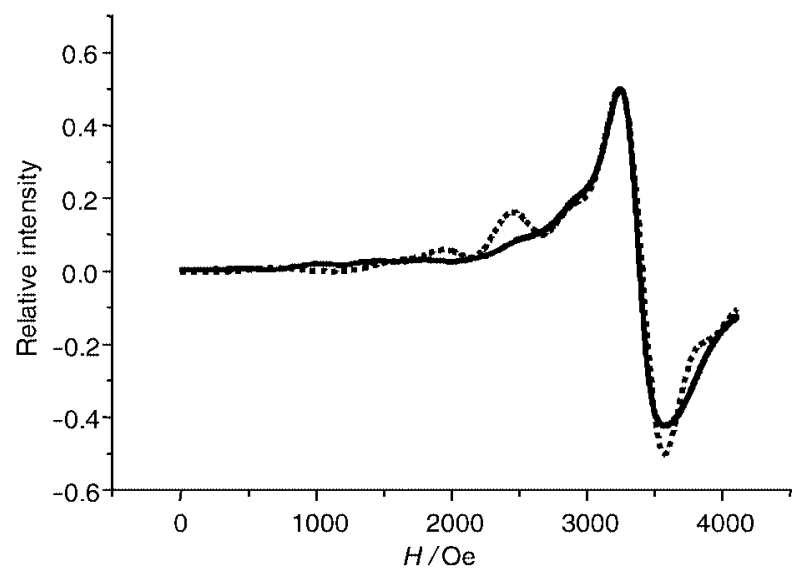

Fig. 4 Experimental (solid line) and calculated (dotted line) EPR spectra of $\left[\mathrm{Gd}\left(\mathrm{A}_{4} \mathrm{bL}^{4}\right)\left(\mathrm{H}_{2} \mathrm{O}\right)\right]\left(\mathrm{CF}_{3} \mathrm{SO}_{3}\right)_{3}$ at $120 \mathrm{~K}$.

square with a fold angle of $155^{\circ}$. The four $\mathrm{O}$ (ether) $-\mathrm{C}-\mathrm{C}-\mathrm{O}-$ (amide) torsion angles are small and with alternate negative and positive values: $-2,7,-5$ and $5^{\circ}$ so that the chirality around the metal atom can be described by $\Delta(\lambda \delta \lambda \delta)$ for the complex of Fig. 2. Within a unit cell, complexes of opposite chirality are present in equimolar amounts resulting in a racemic mixture. On the other hand, the $\mathrm{Lu}-\mathrm{O}$ (amide) $-\mathrm{C}-\mathrm{N}$ torsion angles are all negative $\left(-159(2)\right.$ to $\left.-166(1)^{\circ}\right)$, resulting in the four $\mathrm{Lu}-\mathrm{O}$ (amide) $\mathrm{C}$ strands being oriented in a clockwise fashion. The water molecule is firmly held in the centre of the cavity defined by the four $\mathrm{O}$ (ether) $-\mathrm{CH}_{2}-\mathrm{CH}_{2}-\mathrm{O}$ (phenol) strands by a strong, relatively short ion-dipole bond to $\mathrm{Lu}^{\mathrm{III}}$ and by hydrogen bonding to the phenolic $\mathrm{O}$-atoms, the contact distance $\mathrm{O}(\mathrm{w})-\mathrm{O}($ phenol $)$ ranging between 2.76(1) and 2.82(1) $\AA$. Such an inclusioncomplexation feature has been observed previously for DMSO in the case of an $\mathrm{Eu}^{\mathrm{III}}$ complex with calix[5]arene. ${ }^{32}$ Another peculiarity of the structure is the presence of a diethyl ether molecule included in the hydrophobic cavity defined by the phenol rings and which, like the co-ordinated water molecule, is arranged along a pseudo $C_{4}$ axis going through the metal ion. This solid state structure therefore confirms previous inferences based on vibrational data which show co-ordination of both the carbonyl and ether moieties and the implication of the phenoxide groups in some kind of interaction. Moreover, the NMR spectra demonstrate that this solid state structure is maintained in solution and the unusual shift experienced by the co-ordinated water molecule can now be easily explained. The relatively large stability of the $1: 1$ complexes in acetonitrile despite the presence of four weakly co-ordinating ether groups in the first co-ordination sphere of the metal ions can be traced back to the wrapping of the four arms creating a protective cavity made rigid by the presence of hydrogen bonds between the bound water molecule and the phenolic functions. No stacking has been observed in the crystal packing.

\section{Electron paramagnetic resonance}

The EPR spectra of a powdered sample of the $\mathrm{Gd}^{\mathrm{III}}$ complex at 295 and $120 \mathrm{~K}$ are similar (Fig. 4). They have $g$-values centred at 2.05554 and 2.06150 with line widths of 268 and 333 Gauss, respectively, and they display a fine structure. The broadening of the signal at lower temperature suggests that spin-spin relaxation and electron dipole-nucleus dipole interaction ${ }^{33}$ could be the dominant processes in the interaction of the uncoupled electrons of $\mathrm{Gd}^{\mathrm{III}}$ with its environment. Spin-orbit coupling is not effective in $\mathrm{Gd}^{\mathrm{III}}$ since its first excited state ${ }^{6} \mathrm{P}_{7 / 2}$ is $30000 \mathrm{~cm}^{-1}$ above the fundamental state, so that temperature independent paramagnetism can be neglected (second-order perturbation in the van Vleck equation). The fine structure should display $2 S$ lines, generated by zero-field splitting and thus seven resonances should be observed, ${ }^{34}$ but only six are clearly seen. In order to analyse this structured feature we have simulated the spectrum from 6 to 4105 Gauss with F. Neese's program ${ }^{35}$ based on the perturbation theory; the following Hamiltonian describes the experimental spectrum:

$$
H=D\left[S_{z}^{2}-1 / 3 S(S+1)\right]+\beta H g S
$$

where the first term represents the zero-field splitting (zfs) and the second the electronic isotropic Zeeman interaction. The following parameters reproduced the spectrum: $D$ (anisotropic) $=1300 \mathrm{MHz}\left(0.0434 \mathrm{~cm}^{-1}\right), g$ (isotropic $)=2.05, g=h v / \beta H$ (here $v=9.78 \mathrm{GHz}$ ), $S=7 / 2$. A better fit with the experimental spectrum is obtained when a Gaussian rather than Lorentzian line shape is taken into consideration with an isotropic line width of 200 Gauss $(W)$. The relatively important contribution from the $D$ term reflects a significant $\mathrm{zfs}$ effect. Although this is not yet well understood theoretically, calculations taking into account admixture of $0-3 \%$ of excited states in the ground state multiplet ${ }^{8} \mathrm{~S}_{7 / 2}$ (mainly from the nearest excited multiplet ${ }^{6} \mathrm{P}_{7 / 2}$ ) caused by crystal field effects have led to $D \approx 0.05 \mathrm{~cm}^{-1}{ }^{34}$ Therefore, the $D$ value found here indicates an appreciable interaction between $\mathrm{Gd}^{\mathrm{III}}$ and the ligand. Since the signal is broader at low temperature by about $20 \%$ compared to room temperature, and additionally is of Gaussian line shape, the spin-spin interaction of the unpaired electrons with the environment is the most important process in the complex. The existence of a zfs effect and the value of the $D$ parameter reflect an anisotropy in the system, ${ }^{34,36}$ consistent with the co-ordination geometry found in the crystal structure of the Lu complex.

\section{Photophysical properties}

The photophysical properties of the free ligand and its complexes have been studied in the solid state and in solution. Absorption spectra of $0.1-1 \times 10^{-5} \mathrm{M}$ solutions of $\mathrm{A}_{4} \mathrm{bL}^{4}$ and its complexes in acetonitrile do not show much variation, excepting intensity changes, neither upon complexation, nor with the lanthanide ion. An intense band is present at $220 \mathrm{~nm}$ (45455 $\mathrm{cm}^{-1}$ ) which corresponds to transitions involving orbitals mainly located on the $\mathrm{C}=\mathrm{O}$ groups, while a less intense, structured band at $276 \mathrm{~nm}\left(36230 \mathrm{~cm}^{-1}\right)$, with a shoulder at 284 $\mathrm{nm}\left(35210 \mathrm{~cm}^{-1}\right)$, is associated with the $\pi \longrightarrow \pi^{*}$ transitions involving orbitals mainly located on the phenyl rings. The molar absorption coefficient of the latter amounts to 3370 , $4070,4170,4470$ and $3690 \mathrm{M}^{-1} \mathrm{~cm}^{-1}$ for $\mathrm{A}_{4} \mathrm{bL}^{4}$ and the $\mathrm{Eu}^{\mathrm{III}}$, $\mathrm{Gd}^{\mathrm{III}}, \mathrm{Tb}^{\mathrm{III}}$, and $\mathrm{Lu}^{\mathrm{III}}$ complexes, respectively. In the solid state, the corresponding transitions appear at 45260 and $36660 \mathrm{~cm}^{-1}$ (shoulder at $34920 \mathrm{~cm}^{-1}$ ) on the reflectance spectra.

Ligand-centred luminescence has been investigated on the free ligand and on complexes with $\mathrm{Gd}^{\mathrm{III}}$ and $\mathrm{Lu}^{\mathrm{III}}$. For the free ligand in the solid state or in solution, the excitation spectra match the reflectance and absorption spectra, respectively. At room temperature, excitation at $275 \mathrm{~nm}\left(36360 \mathrm{~cm}^{-1}\right)$ results in an emission spectrum with a unique broad band centred at 307 $\mathrm{nm}$ (free ligand, $32570 \mathrm{~cm}^{-1}$ ) or $308 \mathrm{~nm}$ (complexed ligand, $32470 \mathrm{~cm}^{-1}$ ) and assigned as arising from the lowest ${ }^{1} \pi \pi^{*}$ state of the ligand. In frozen solution at $77 \mathrm{~K}$, an additional broad band appears corresponding to emission from the ${ }^{3} \pi \pi^{*}$ state which is located at $463 \mathrm{~nm}$ (free ligand, $21600 \mathrm{~cm}^{-1}$ ), $425 \mathrm{~nm}$ $\left(\mathrm{Gd}^{\mathrm{III}}, 23530 \mathrm{~cm}^{-1}\right)$ or $465 \mathrm{~nm}\left(\mathrm{Lu}^{\mathrm{III}}, 21505 \mathrm{~cm}^{-1}\right)$. The energy of the observed ${ }^{3} \pi \pi^{*}$ state is close to that measured for the $2: 2$ $\mathrm{Gd}^{\mathrm{III}}$ complex with p-tert-butylcalix[5] arene $\left(23640 \mathrm{~cm}^{-1}\right.$ at room temperature in THF solution). ${ }^{32}$ Intersystem crossing is an important step in the ligand-to- $\mathrm{Ln}^{\mathrm{III}}$ energy migration path and it has been reported for a series of $\mathrm{Ln}^{\mathrm{III}}$ complexes $(\mathrm{Ln}=$ $\mathrm{Eu}, \mathrm{Tb})$ with functionalised calix[4]arenes that this transfer is maximised when the $\Delta E\left({ }^{1} \pi \pi^{*}-{ }^{3} \pi \pi^{*}\right)$ is $c a .5000 \mathrm{~cm}^{-1}$. In our case this energy difference is much larger $\left(9-11000 \mathrm{~cm}^{-1}\right)$, so that very efficient energy transfer from the ligand onto the luminescent $\mathrm{Eu}^{\mathrm{III}}$ and $\mathrm{Tb}^{\mathrm{III}}$ ions is not expected, despite the fact 


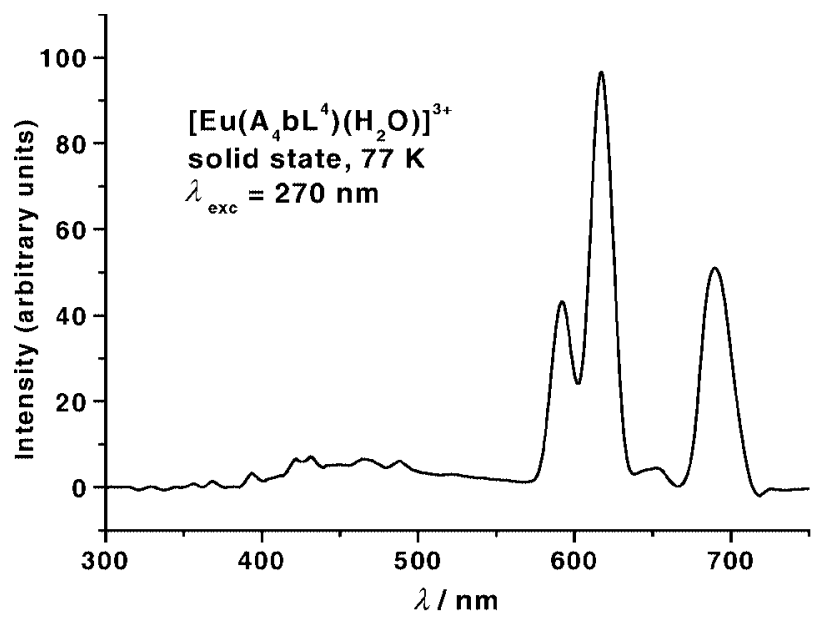

Fig. 5 Emission spectrum of $\left[\mathrm{Eu}\left(\mathrm{A}_{4} \mathrm{bL}^{4}\right)\left(\mathrm{H}_{2} \mathrm{O}\right)\right]^{3+}$ at $77 \mathrm{~K}$ in the solid state.

that the triplet state possesses adequate energy according to Latva and co-workers who have noted that optimised energy transfer happens when the energy of the 0-phonon component of the ${ }^{3} \pi \pi^{*}$ state is located in the range $21-22000 \mathrm{~cm}^{-1} \cdot{ }^{37} \mathrm{In}$ addition, the distance between the lanthanide ion and the chromophoric unit is large, so that exchange (Dexter) mechanisms are minimised, leading to a decrease of the overall energy transfer process. The ${ }^{3} \pi \pi^{*}$ state lifetime amounts to $227 \pm 17$ (Lu complex) and $56 \pm 5 \mathrm{~ms}$ (Gd complex), the latter value being close to that reported for the complex formed with $p$ tert-butylcalix[4]arene tetra-acetamide $\left(\mathrm{L}^{0}: 69 \mathrm{~ms}\right.$ at $77 \mathrm{~K}$ in $\left.\mathrm{CH}_{2} \mathrm{Cl}_{2}-\mathrm{MeOH} 1 / 1 \mathrm{v} / \mathrm{v}\right) .{ }^{17}$

The Eu $\mathrm{Eu}^{\mathrm{III}}$ and $\mathrm{Tb}^{\mathrm{III}}$ complexes display the characteristic metal-centred luminescence, both at room temperature and at $77 \mathrm{~K}$. The excitation spectrum of a solid sample of [Eu$\left.\left(\mathrm{A}_{4} \mathrm{bL}^{4}\right)\left(\mathrm{H}_{2} \mathrm{O}\right)\right]^{3+}$ (Fig. S4, ESI) displays bands corresponding to the ligand ${ }^{1} \pi \pi^{*}$ state and to metal-centred transitions ${ }^{5} \mathrm{D}_{n} \longleftarrow{ }^{7} \mathrm{~F}_{0}$ $(n=1-3)$, indicating sensitisation of the metal ion by the $\mathrm{A}_{4} \mathrm{bL}^{4}$ ligand. However, the emission spectrum (Fig. 5) also displays residual emission from the ligand ${ }^{3} \pi \pi^{*}$ triplet state in the range $400-490 \mathrm{~nm}$, pointing to an incomplete energy transfer. The spectrum at $12 \mathrm{~K}$ displays broad bands with a very weak ${ }^{5} \mathrm{D}_{0} \longrightarrow$ ${ }^{7} \mathrm{~F}_{0}$ transition, one band for each of the ${ }^{5} \mathrm{D}_{0} \rightarrow{ }^{7} \mathrm{~F}_{1}$ and ${ }^{5} \mathrm{D}_{0} \rightarrow$ ${ }^{7} \mathrm{~F}_{2}$ transitions and two bands for each transition to the ${ }^{7} \mathrm{~F}_{3}$ and ${ }^{7} \mathrm{~F}_{4}$ sub-levels, that is, a pattern consistent with the coordination polyhedron discussed above for the $\mathrm{Lu}^{\mathrm{III}}$ complex. The luminescence decay is mono-exponential, consistent with the presence of a single $\mathrm{Eu}^{\mathrm{III}}$ site, and the $\mathrm{Eu}\left({ }^{5} \mathrm{D}_{0}\right)$ lifetimes obtained by excitation through the ligand ${ }^{1} \pi \pi^{*}$ state $\left(32480 \mathrm{~cm}^{-1}\right)$ or through the $\operatorname{Eu}\left({ }^{5} \mathrm{~L}_{6}\right)$ level $\left(25380 \mathrm{~cm}^{-1}\right)$ are slightly temperature-dependent, decreasing from $0.50 \pm 0.01 \mathrm{~ms}$ at $20 \mathrm{~K}$ to $0.38 \pm 0.02 \mathrm{~ms}$ at $295 \mathrm{~K}$. Both this dependence and the relatively low value of the lifetimes are consistent with a non-radiative deactivation process taking place through $\mathrm{OH}$ oscillators from co-ordinated water molecule(s). The coordination of one water molecule would lead to a lifetime of approximately $0.6-0.7 \mathrm{~ms}^{38}$ The difference with respect to the experimental value may be explained by more water molecule(s) being bound either directly to the metal ion or lying in the second co-ordination sphere (elemental analysis points to a compound with three water molecules). The influence of proximate energy-matched $\mathrm{OH}$ oscillators on the de-activation of $\mathrm{Ln}^{\mathrm{III}}$ ions has indeed been recently documented for complexes with cyclen derivatives. ${ }^{39}$ Alternatively, an additional quenching mechanism may also be invoked. For instance, we note that quenching through a low lying charge-transfer state (LMCT) between the carbonyl groups and $\mathrm{Eu}^{\mathrm{III}}$ has been invoked to explain the photophysical properties of the complex with $\mathrm{L}^{0}{ }^{17}$ Since four carbonyl functions occupy the inner co-ordination sphere of the metal ion in $\left[\mathrm{Eu}\left(\mathrm{A}_{4} \mathrm{bL}^{4}\right)\left(\mathrm{H}_{2} \mathrm{O}\right)\right]^{3+}$, a similar explanation could be put forward. However, we were unable to evidence a LMCT state neither in the absorption nor in the excitation spectra.

It is noteworthy that the lifetime of solutions in acetonitrile $\left(10^{-3}-10^{-5} \mathrm{M}\right)$ is larger than in the solid state, reaching $0.73 \pm$ $0.05 \mathrm{~ms}$, a value consistent with one inner-sphere water molecule and also in line with the observation made for the complex with $\mathrm{L}^{0}$ for which the non-radiative deactivation rate due to the LMCT is twice as large in the solid state as in solution. ${ }^{17}$ The relative quantum yield of the Eu-centred luminescence has been measured upon ligand excitation at $279 \mathrm{~nm}$ and amounts to $2 \%$, a low value which can be traced back to the relatively poor photophysical properties of the molecular assembly, as discussed above.

The emission spectrum of a solid sample of the $\mathrm{Tb}^{\mathrm{III}}$ complex displays the ${ }^{5} \mathrm{D}_{4} \longrightarrow{ }^{7} \mathrm{~F}_{J}$ transitions and residual emission from the ligand triplet state. The $\mathrm{Tb}\left({ }^{5} \mathrm{D}_{4}\right)$ luminescence decay is mono-exponential and the lifetime, obtained upon excitation through the ligand states, is slightly temperature dependent, varying from $2.08 \pm 0.01$ at $11 \mathrm{~K}$ to $1.45 \pm 0.01 \mathrm{~ms}$ at $295 \mathrm{~K}$. In solution at room temperature, the lifetime is identical to the latter value: $\tau=1.42 \pm 0.09 \mathrm{~ms}$, again consistent with the explanation given above for the small $\mathrm{Eu}\left({ }^{5} \mathrm{D}_{0}\right)$ lifetime in the solid state since the LMCT state lies at much higher energy for $\mathrm{Tb}^{\mathrm{III}}$ and will therefore not interfere with the ion de-excitation. We note that this lifetime is close to the one found for cationic complexes with cyclen derivatives for which one water molecule is co-ordinated onto the metal ion $(\mathrm{ca} .1 .6 \mathrm{~ms}) .{ }^{39}$ The absolute quantum yield was found to be $5.8 \%$ in acetonitrile.

\section{Conclusion}

We have shown that $p$-tert-butylcalix[4]arene can be easily functionalised by ether-amide pendant arms and that the resulting macrocycle leads to stable $1: 1$ complexes with lanthanide ions in acetonitrile. The crystal structure of the $\mathrm{Lu}^{\mathrm{III}}$ complex shows that the four ligand arms wrap around the metal ion, forming a protective cavity, which is made rigid by the presence of one inner-sphere water molecule inserted into the arm cavity and implied hydrogen bonds to the phenolic oxygen atoms. The latter effect probably offsets the entropic disadvantage of long pendant arms and opens the way to the design of predisposed ligands bearing elongated arms without losing their complexation ability towards lanthanide ions. The hydrophobic cavity formed by the aromatic rings of the calixarene hosts an organic molecule (here diethyl ether) so that the synthesised pendant arm calixarene acts as a mixed inorganic-organic receptor. The experimental results gathered both in the solid state (X-ray diffraction, IR, EPR, luminescence spectra and lifetimes) are consistent with a series of compounds ( $\mathrm{Eu}, \mathrm{Gd}, \mathrm{Tb}, \mathrm{Lu})$ displaying a similar structure and solution studies (NMR, luminescence) suggest that this structure is essentially retained in acetonitrile. The photophysical properties of the complexes with $\mathrm{Eu}^{\mathrm{III}}$ and $\mathrm{Tb}^{\mathrm{III}}$ are not optimum and the quantum yields measured in acetonitrile are relatively low. However, further derivatisation of the arms with more adequate groups ${ }^{40}$ could easily lead to more luminescent edifices. Moreover, this study demonstrates once more the potentiality borne by the calixarene platform to complex simultaneously inorganic and organic guests, a fact which could be of importance in the modelling and design of extraction processes. Indeed, recent molecular dynamics and quantum mechanical simulations have demonstrated the sensitivity of these processes to experimental conditions such as counteranion and solvent composition. ${ }^{9}$

\section{Experimental}

\section{Solvents and starting materials}

Diglycolic anhydride, $\mathrm{BH}_{3} \cdot \mathrm{Me}_{2} \mathrm{~S}$ (2M solution in THF), $\mathrm{Et}_{2} \mathrm{NH}, \mathrm{Et}_{3} \mathrm{~N}$, and $\mathrm{SOBr}_{2}$ (Fluka AG, Buchs, Switzerland) 
and p-tert-butylcalix[4]arene (Acros Chemicals) were used without purification. Tetrahydrofuran and toluene were distilled over $\mathrm{Na}$ and acetonitrile over $\mathrm{CaH}_{2}$. Lanthanide trifluoromethanesulfonates (triflates) were prepared from the oxides (Rhône-Poulenc, 99.99\%) and triflic acid. Elemental analyses were performed by Dr H. Eder (Microchemical Laboratory, University of Geneva, Switzerland).

\section{Synthesis of the ligands}

Diethylcarbamoylmethoxy acetic acid 2. In a $100 \mathrm{~cm}^{3}$ flask, $2 \mathrm{~g}(15.5 \mathrm{mmol})$ of $90 \%$ diglycolic anhydride were dissolved in $20 \mathrm{~cm}^{3}$ of $\mathrm{CH}_{2} \mathrm{Cl}_{2}$ containing $3.6 \mathrm{~cm}^{3}$ (31 mmol, 2.2 eq.) of diethylamine. The solution was refluxed for $2 \mathrm{~h}$. The organic solution was washed with $30 \mathrm{~cm}^{3}$ of $6 \% \mathrm{HCl}$ in water and the water layer was extracted twice with $40 \mathrm{~cm}^{3} \mathrm{CH}_{2} \mathrm{Cl}_{2}$. The combined organic layers were dried over $\mathrm{MgSO}_{4}$, filtered and evaporated to dryness to give $2.38 \mathrm{~g}$ (yield $=81 \%$ ) of 2 as a white solid. ${ }^{1} \mathrm{H}-\mathrm{NMR}\left(\mathrm{CDCl}_{3} ; 200 \mathrm{MHz}\right): \delta 1.17\left(\mathrm{t}, 3 \mathrm{H},{ }^{3} \mathrm{~J}=7.0 \mathrm{~Hz}\right)$, $1.22\left(\mathrm{t}, 3 \mathrm{H},{ }^{3} J=7.5 \mathrm{~Hz}\right), 3.20\left(\mathrm{q}, 2 \mathrm{H},{ }^{3} J=7.0 \mathrm{~Hz}\right), 3.44(\mathrm{q}$ $\left.2 \mathrm{H},{ }^{3} \mathrm{~J}=7.0 \mathrm{~Hz}\right), 4.22(\mathrm{~s}, 2 \mathrm{H}), 4.40(\mathrm{~s}, 2 \mathrm{H}) .{ }^{13} \mathrm{C}-\mathrm{NMR}\left(\mathrm{CDCl}_{3}\right.$, $50 \mathrm{MHz}): 12.5,13.6\left(\mathrm{C}_{\text {prim. }}\right), 40.9,41.0,70.9,72.4\left(\mathrm{C}_{\text {sec. }}\right), 170.2$, $172.0\left(\mathrm{C}_{\text {quat. }}\right)$.

$\mathrm{N}, \mathrm{N}$-Diethyl-2-(2-hydroxyethoxy)acetamide 3 . In a $100 \mathrm{~cm}^{3}$ two-necked flask under nitrogen, $1.55 \mathrm{~g}(8.2 \mathrm{mmol})$ of 2 were dissolved in $20 \mathrm{~cm}^{3}$ of dry THF; $4.5 \mathrm{~cm}^{3}$ of a $2 \mathrm{M}$ solution of $\mathrm{BH}_{3} \cdot \mathrm{Me}_{2} \mathrm{~S}$ in THF were added dropwise to the solution cooled at $0{ }^{\circ} \mathrm{C}$. The resulting mixture was warmed to $\mathrm{rt}$ and was further stirred for $3 \mathrm{~h} ; 10 \mathrm{~cm}^{3}$ water were slowly added and a white precipitate formed which dissolved upon addition of $40 \mathrm{~cm}^{3}$ $10 \% \mathrm{HCl}$. THF was slowly evaporated under reduced pressure and the aqueous layer was washed three times with $40 \mathrm{~cm}^{3}$ $\mathrm{CH}_{2} \mathrm{Cl}_{2}$. The combined organic phases were washed with $40 \mathrm{~cm}^{3}$ of a half saturated solution of $\mathrm{Na}_{2} \mathrm{CO}_{3}$ in water, dried over $\mathrm{MgSO}_{4}$, filtered and evaporated to dryness, to give $1.04 \mathrm{~g}$ (yield $=72 \%)$ of 3 as a yellowish oil. ${ }^{1} \mathrm{H}-\mathrm{NMR}\left(\mathrm{CDCl}_{3}, 200 \mathrm{MHz}\right)$ $\delta 1.09\left(\mathrm{t}, 3 \mathrm{H},{ }^{3} J=7.0 \mathrm{~Hz}\right), 1.14\left(\mathrm{t}, 3 \mathrm{H},{ }^{3} J=7.0 \mathrm{~Hz}\right), 3.19(\mathrm{q}$ $\left.2 \mathrm{H},{ }^{3} J=7.2 \mathrm{~Hz}\right), 3.31\left(\mathrm{q}, 2 \mathrm{H},{ }^{3} J=7.0 \mathrm{~Hz}\right), 3.60-3.66(\mathrm{~m}, 4 \mathrm{H})$, $4.18(\mathrm{~s}, 2 \mathrm{H}), 4.38$ (s, br, $1 \mathrm{H}) .{ }^{13} \mathrm{C}-\mathrm{NMR}\left(\mathrm{CDCl}_{3}, 50 \mathrm{MHz}\right)$ $12.9,14.1\left(\mathrm{C}_{\text {prim. }}\right), 40.3,40.8,61.5,69.1,73.7\left(\mathrm{C}_{\text {sec. }}\right), 169.1$ $\left(\mathrm{C}_{\text {quat. }}\right)$.

2-(2-Bromoethoxy)- $N, N$-diethylacetamide 4. A quantity of $5.8 \mathrm{~g}$ of $3(33.1 \mathrm{mmol})$ was dissolved in $300 \mathrm{~cm}^{3} \mathrm{CH}_{3} \mathrm{CN}$ put into a $500 \mathrm{~cm}^{3}$ two-necked flask, to which $5.6 \mathrm{~cm}^{3}(40.2 \mathrm{mmol})$ of $\mathrm{Et}_{3} \mathrm{~N}$ were added, followed by $9.2 \mathrm{~g}(44.3 \mathrm{mmol})$ of $\mathrm{SOBr}_{2}$. The reaction mixture was refluxed for $14 \mathrm{~h}$ under a nitrogen atmosphere with slow stirring. After cooling to room temperature and filtering, the resulting solution was mixed with an equal volume of water and extracted twice with $300 \mathrm{~cm}^{3}$ $\mathrm{CH}_{2} \mathrm{Cl}_{2}$. The organic layer was washed with water until $\mathrm{pH} \approx 7$ to remove the excess $\mathrm{Et}_{3} \mathrm{~N}$ and $\mathrm{SOBr}_{2}$, dried over $\mathrm{MgSO}_{4}$, filtered and treated with activated charcoal. After column chromatography (silica gel, $35 \mathrm{~cm}$ column, $3 \mathrm{~cm}$ diameter, packed with $\mathrm{CH}_{2} \mathrm{Cl}_{2}$; eluent: $\mathrm{CH}_{2} \mathrm{Cl}_{2}-\mathrm{MeOH}(0.5-4 \%)$ v/v mixtures), $1.7 \mathrm{~g}(7.1 \mathrm{mmol})$ of 4 (yield $=56 \%)$ were obtained as a brown-reddish oil $\left(R_{\mathrm{f}}=0.50\right.$, TLC plate $\mathrm{SiO}_{2} ; \mathrm{CH}_{2} \mathrm{Cl}_{2}-i-\mathrm{PrOH}-$ hexane $160: 10: 30, \mathrm{v} / \mathrm{v}) .{ }^{1} \mathrm{H}-\mathrm{NMR}\left(\mathrm{CDCl}_{3}, 360 \mathrm{MHz}\right): \delta 4.21$ $\left(\mathrm{s}, 2 \mathrm{H}, \mathrm{H}^{3}\right), 3.89\left(2 \mathrm{H}, \mathrm{t},{ }^{3} J=6.0 \mathrm{~Hz}, \mathrm{H}^{2}\right), 3.52\left(2 \mathrm{H}, \mathrm{t},{ }^{3} J=\right.$ $\left.6.0 \mathrm{~Hz}, \mathrm{H}^{1}\right), 3.41\left(2 \mathrm{H}, \mathrm{q},{ }^{3} J=7.0 \mathrm{~Hz}, \mathrm{H}^{5}\right), 3.34\left(2 \mathrm{H}, \mathrm{q},{ }^{3} J=7.0\right.$ $\left.\mathrm{Hz}, \mathrm{H}^{5}\right), 1.19\left(3 \mathrm{H}, \mathrm{t},{ }^{3} J=7.0 \mathrm{~Hz}, \mathrm{H}^{6}\right), 1.13\left(3 \mathrm{H}, \mathrm{t},{ }^{3} J=7.0 \mathrm{~Hz}\right.$, $\left.\mathrm{H}^{6}\right)$. CI-MS: $m / z$ 238, $240\left(\mathrm{M}+1\right.$, calc. $\left({ }^{79} \mathrm{Br}\right) 238.1$, calc. $\left({ }^{81} \mathrm{Br}\right)$ 240.1). IR ( $\left.\mathrm{cm}^{-1}, \mathrm{KBr}\right): 1646\left(v_{\mathrm{C}=\mathrm{O}}\right), 1119 v_{\mathrm{O}-\mathrm{CH}_{2}}$.

5,11,17,23-Tetra-tert-butyl-25,26,27,28-tetrakis[2-(diethylcarbamoylmethoxy)ethoxy]calix[4]arene, $\mathbf{A}_{4} \mathbf{b L}^{4}$. An emulsion of the tetrasodium derivative of p-tert-butylcalix[4]arene, prepared by addition of $\mathrm{NaH}(0.17 \mathrm{~g}, 60 \%$ in mineral oil, $4.3 \mathrm{mmol})$ to a solution of dried calixarene $(0.200 \mathrm{~g}, 0.31 \mathrm{mmol})$ in dried toluene $\left(40 \mathrm{~cm}^{3}\right)$ was heated with stirring at $72{ }^{\circ} \mathrm{C}$ under a rapid flow of nitrogen until the spot corresponding to free p-tert-butylcalix[4]arene disappeared on the TLC plate $\left(R_{\mathrm{f}}=\right.$ $0.80, \mathrm{SiO}_{2}, \mathrm{CH}_{2} \mathrm{Cl}_{2}-i-\mathrm{PrOH}-$ hexane $160: 10: 30$, v/v). The mixture was added dropwise to a solution of dried 4 (1.03 g, $4.3 \mathrm{mmol})$ in toluene $\left(5 \mathrm{~cm}^{3}\right)$ at $115^{\circ} \mathrm{C}$. The resulting mixture was stirred and refluxed under nitrogen for 5 days. After cooling at $\mathrm{rt}$ the mother liquor was filtered and the resulting solution was washed with doubly distilled water until no $\mathrm{AgBr}$ precipitate was formed upon addition of $2 \% \mathrm{AgNO}_{3}$. After evaporation of the solvent, the crude solid was dried under high vacuum $\left(10^{-5} \mathrm{mmHg}, 55-60^{\circ} \mathrm{C}, 24 \mathrm{~h}\right)$, washed with hexane and dried again $\left(10^{-5} \mathrm{mmHg}, 100{ }^{\circ} \mathrm{C}, 48 \mathrm{~h}\right)$ to give $0.174 \mathrm{~g}(0.14$ mmol, yield $=50 \%$ ) of a slightly brownish husk-like powder. (Found: C, 70.39; $\mathrm{H}, 9.10 ; \mathrm{N}, 4.35 ; \mathrm{C}_{76} \mathrm{H}_{116} \mathrm{O}_{12} \mathrm{~N}_{4} \cdot \mathrm{H}_{2} \mathrm{O}$ requires C, 70.45; H, 9.18; N, 4.32\%.) IR ( $\left.\mathrm{cm}^{-1}, \mathrm{KBr}\right): 1651\left(v_{\mathrm{C}=\mathrm{O}}\right), 1123$ $\left(v_{\mathrm{O}-\mathrm{CH}_{2}}\right), 1203$ and $1053\left(v_{\mathrm{Ar}-\mathrm{O}}\right)$. ES-MS $\left(\mathrm{MeOH}-\mathrm{HCO}_{2} \mathrm{H}\right)$ : $m / z 1277.82\left(\mathrm{M}^{+\bullet}\right), 1295.82\left(\mathrm{M}^{+\bullet}+\mathrm{H}_{2} \mathrm{O}\right), 1299.38(\mathrm{M}+\mathrm{Na})^{+}$. ${ }^{1} \mathrm{H}-\mathrm{NMR}$ (degassed and dried $\mathrm{CD}_{3} \mathrm{CN}, 400 \mathrm{MHz}$ ): $\delta 7.06$ (s, $\left.8 \mathrm{H}, \mathrm{H}^{8}, \mathrm{H}^{10}\right), 4.53\left(\mathrm{~d}, 4 \mathrm{H},{ }^{2} J=12.0, \mathrm{H}^{13}{ }_{\mathrm{ax}}\right), 4.27\left(\mathrm{~s}, 8 \mathrm{H}, \mathrm{H}^{3}\right)$, $4.15\left(\mathrm{t}, 8 \mathrm{H},{ }^{3} \mathrm{~J}=5.5 \mathrm{~Hz}, \mathrm{H}^{1}\right), 4.04\left(\mathrm{t}, 8 \mathrm{H},{ }^{3} J=5.5 \mathrm{~Hz}, \mathrm{H}^{2}\right)$, $3.36-3.28\left(\mathrm{~m}, 16 \mathrm{H}, \mathrm{H}^{5}\right), 3.24\left(\mathrm{~d}, 4 \mathrm{H},{ }^{3} \mathrm{~J}=12.5 \mathrm{~Hz}, \mathrm{H}^{13}{ }_{\text {eq }}\right), 1.16$ $(\mathrm{s}, 36 \mathrm{H}, t-\mathrm{Bu}), 1.13\left(\mathrm{t}, 12 \mathrm{H}, \mathrm{H}^{6}\right), 1.08\left(\mathrm{t}, 12 \mathrm{H}, \mathrm{H}^{6}\right),{ }^{13} \mathrm{C}-\left\{{ }^{1} \mathrm{H}\right\}-$ NMR (CD $\left.{ }_{3} \mathrm{CN}, 50 \mathrm{MHz}\right): \delta 169.2\left(\mathrm{C}^{4}\right), 154.5\left(\mathrm{C}^{12}\right), 146.5\left(\mathrm{C}^{9}\right)$, $135.1\left(\mathrm{C}^{7}, \mathrm{C}^{11}\right), 126.3\left(\mathrm{C}^{8}, \mathrm{C}^{10}\right), 74.2,71.4\left(\mathrm{C}^{1}, \mathrm{C}^{2}\right), 70.5$

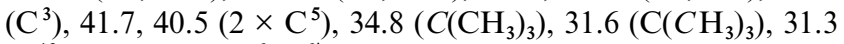
$\left(\mathrm{C}^{13}\right), 14.6,13.5\left(\mathrm{C}^{6}, \mathrm{C}^{6}\right)$.

\section{Syntheses of the complexes}

$\mathrm{Ln}\left(\mathrm{CF}_{3} \mathrm{SO}_{3}\right)_{3} \cdot x \mathrm{H}_{2} \mathrm{O}(\mathrm{Ln}=\mathrm{Eu}, \mathrm{Gd}, \mathrm{Tb}$ and $\mathrm{Lu}, 0.02 \mathrm{mmol})$ was dissolved in $1 \mathrm{~cm}^{3}$ of dried $\mathrm{MeCN}$ at $36{ }^{\circ} \mathrm{C}$, stirred under $\mathrm{N}_{2}$ and an equimolar amount of $\mathrm{A}_{4} \mathrm{bL}^{4}$ in $2 \mathrm{~cm}^{3}$ of dried $\mathrm{MeCN}$ was added dropwise. The resulting mixture was stirred during $1 \mathrm{~h}$, cooled to $\mathrm{rt}$ and further stirred for $4 \mathrm{~h}$. The solvent was partially evaporated under vacuum and diisopropyl ether was added dropwise until the solution became cloudy. The mixture was left overnight at $-20{ }^{\circ} \mathrm{C}$. The precipitate was centrifuged, washed with $2 \mathrm{~cm}^{3}$ diisopropyl ether and dried at $80{ }^{\circ} \mathrm{C}$ for $24 \mathrm{~h}$ under vacuum $\left(4 \times 10^{-2}\right.$ Torr $)$. The four complexes were hygroscopic. Yield: $88(\mathrm{Eu}), 81(\mathrm{Gd}) 91(\mathrm{~Tb})$ and $73 \%(\mathrm{Lu})$. (Found: C, 48.94; $\mathrm{H}, 6.36 ; \mathrm{N}, 3.01$. Calc. for $\mathrm{Eu}\left(\mathrm{CF}_{3} \mathrm{SO}_{3}\right)_{3}$. $\mathrm{A}_{4} \mathrm{bL}^{4} \cdot 3 \mathrm{H}_{2} \mathrm{O}: \mathrm{C}, 49.14 ; \mathrm{H}, 6.37 ; \mathrm{N}, 2.90 \%$. Found: $\mathrm{C}, 45.73 ; \mathrm{H}$, 6.07; N, 2.82. Calc. for $\mathrm{Gd}\left(\mathrm{CF}_{3} \mathrm{SO}_{3}\right)_{3} \cdot \mathrm{A}_{4} \mathrm{bL}^{4} \cdot 6 \mathrm{H}_{2} \mathrm{O}: \mathrm{C}, 47.65 ; \mathrm{H}$, $6.48 ; \mathrm{N}, 2.82 \%$. Found: C, 46.19; H, 6.14; N, 2.84. Calc. for $\mathrm{Tb}\left(\mathrm{CF}_{3} \mathrm{SO}_{3}\right)_{3} \cdot \mathrm{A}_{4} \mathrm{bL}^{4} \cdot 6 \mathrm{H}_{2} \mathrm{O}: \mathrm{C}, 48.96 ; \mathrm{H}, 6.35 ; \mathrm{N}, 2.89 \%$. Found: C, 44.59; H, 6.14; N, 2.75. Calc. for $\mathrm{Lu}\left(\mathrm{CF}_{3} \mathrm{SO}_{3}\right)_{3} \cdot \mathrm{A}_{4} \mathrm{bL} \cdot 6 \mathrm{H}_{2} \mathrm{O}$ : C, 47.25; H, 6.43; N, 2.79\%). IR ( $\mathrm{cm}^{-1} \mathrm{KBr}$ pellets, $\mathrm{Ln}=\mathrm{Eu}$, $\mathrm{Gd}, \mathrm{Tb}, \mathrm{Lu}): v(\mathrm{CON}) 1616-1620, v_{\mathrm{s}}\left(\mathrm{SO}_{2}\right) 1031, \delta_{\mathrm{as}}\left(\mathrm{SO}_{3}\right) 639$. ${ }^{1} \mathrm{H}-\mathrm{NMR}$ (360 MHz; degassed and anhydrous $\mathrm{CD}_{3} \mathrm{CN}, \mathrm{Ln}=$ $\mathrm{Lu}, 295 \mathrm{~K}): \delta 7.42(4 \mathrm{H}$, broad d, aryl $\mathrm{H}), 7.37(4 \mathrm{H}$, broad d, aryl $\mathrm{H}), 7.05\left(2 \mathrm{H}, \mathrm{s}\right.$, bound $\left.\mathrm{H}_{2} \mathrm{O}\right), 5.36\left(4 \mathrm{H}, \mathrm{d},{ }^{2} J=16.0 \mathrm{~Hz}\right)$, $5.13\left(4 \mathrm{H}, \mathrm{dd},{ }^{2} J=14.5 \mathrm{~Hz},{ }^{3} J=8.5 \mathrm{~Hz}\right), 4.58\left(4 \mathrm{H}, \mathrm{dd},{ }^{2} J=\right.$ $\left.12.5 \mathrm{~Hz},{ }^{3} J=9.5 \mathrm{~Hz}\right), 4.51\left(4 \mathrm{H},{ }^{2} J=14.5 \mathrm{~Hz}\right), 4.22\left(4 \mathrm{H}, \mathrm{d},{ }^{2} J=\right.$ $12.5 \mathrm{~Hz}), 4.13-4.08$ (4 H, m, br), 3.63-3.53 (8 H, m), $3.50(4 \mathrm{H}$, $\left.\mathrm{d},{ }^{2} J=12.5 \mathrm{~Hz}\right), 3.41-3.32(8 \mathrm{H}, \mathrm{m}), 3.26\left(4 \mathrm{H}, \mathrm{dd},{ }^{2} J=13.5 \mathrm{~Hz}\right)$, $2.56\left(10 \mathrm{H}, \mathrm{s}\right.$, free $\left.\mathrm{H}_{2} \mathrm{O}\right), 1.30\left(12 \mathrm{H}, \mathrm{t},{ }^{3} \mathrm{~J}=7.0 \mathrm{~Hz}\right), 1.24(36 \mathrm{H}$, s), $1.19\left(12 \mathrm{H}, \mathrm{t},{ }^{3} J=7.0 \mathrm{~Hz}\right)$. After exchange with $\mathrm{D}_{2} \mathrm{O}: \delta 7.35$ $(8 \mathrm{H}, \mathrm{s}), 5.30$ (4 H, s, br), 5.08 (4 H, s, br), 4.52 (8 H, s, br), 4.18 (d, $\left.{ }^{2} J=12.5 \mathrm{~Hz}\right), 4.10$ (4 H, s, br), $3.50(8 \mathrm{H}, \mathrm{s}, \mathrm{br}), 3.47$ (4 H, d, $\left.{ }^{2} J=12.5 \mathrm{~Hz}\right), 3.39-3.26(16 \mathrm{H}, \mathrm{m}), 1.26\left(12 \mathrm{H}, \mathrm{t},{ }^{3} J=7.5 \mathrm{~Hz}\right)$, $1.21(36 \mathrm{H}, \mathrm{s}), 1.15\left(12 \mathrm{H},{ }^{2} \mathrm{~J}=7.0 \mathrm{~Hz}\right) \cdot{ }^{13} \mathrm{C}-\left\{{ }^{1} \mathrm{H}\right\}-\mathrm{NMR}$ (400 $\mathrm{MHz}$, degassed and anhydrous $\left.\mathrm{CD}_{3} \mathrm{CN}\right): \delta 172.3,\left(\mathrm{C}^{4}\right)$, $152.9\left(\mathrm{C}^{12}\right), 135.7,135.3\left(\mathrm{C}^{7}, \mathrm{C}^{11}\right), 127.7,126.6\left(\mathrm{C}^{8}, \mathrm{C}^{10}\right), 76.8$, 76.4, 76.0 $\left(\mathrm{C}^{1,2}\right), 73.0,72.8\left(\mathrm{C}^{3}\right), 43.5,43.2,43.0\left(\mathrm{C}^{5}\right), 35.0$ $\left(\mathrm{C}\left(\mathrm{CH}_{3}\right)_{3}\right), 31.5,30.7\left(\mathrm{C}\left(\mathrm{CH}_{3}\right)_{3}\right), 13.5,13.4,13.0,12.9\left(\mathrm{C}^{6}\right)$.

\section{Physicochemical measurements}

The IR spectra were measured on a Mattson Alpha Centauri FT spectrometer as $\mathrm{KBr}$ pellets or as film on $\mathrm{AgCl}$ for oily 
samples. ES-MS spectra were measured on a Finnigan SSQ 710C spectrometer driven by a Digital Personal station 5000/25 on $10^{-4} \mathrm{M}$ solutions in methanol or dried acetonitrile. NMR spectra were recorded on Bruker AM-360 or DRX Avance 400 spectrometers; $\delta$ were referenced to TMS or to $\mathrm{CD}_{3} \mathrm{CN}$. Analysis of the NMR data in terms of stability constants was done with the program MINEQL ${ }^{+} .{ }^{24}$ Electron paramagnetic resonance (EPR) spectra were recorded at X-band and from 4 to $6715 \mathrm{G}$ at 300 and $120 \mathrm{~K}$ with a Bruker ECS 106 spectrometer. Low resolution luminescence spectra and lifetimes (at least five determinations) were recorded on a Perkin-Elmer LS-50B spectrofluorimeter at 295 and $77 \mathrm{~K}$. The quantum yields of the metal-centred luminescence were determined in degassed and anhydrous $\mathrm{CH}_{3} \mathrm{CN}$ at room temperature with respect to a corresponding complex with a cyclen derivative $(\mathrm{L}=$ 1,3,7,10-tetrakis[ $N$-(4-phenylacetyl)]carbamoylmethyl-1,4,7,10tetraazacyclododecane $)^{41}$ using the following formula:

$$
Q_{x} / Q_{r}=\left[A_{r}\left(\lambda_{r}\right) / A_{x}\left(\lambda_{x}\right)\right]\left[I\left(\lambda_{r}\right) / I\left(\lambda_{x}\right)\right]\left[n^{2}{ }_{x} / n^{2}{ }_{r}\right]\left[D_{x} / D_{r}\right]
$$

where subscript $r$ stands for the reference and $x$ for the sample; $A$ is the absorbance at the excitation wavelength, $I$ the intensity of the excitation light at the same wavelength, $n$ the refractive index (1.344 for solution in $\mathrm{CH}_{3} \mathrm{CN}$ and 1.333 for the solution in water), and $D$ the integrated luminescence intensity. The same excitation wavelength $(279 \mathrm{~nm})$ and absorbance (0.27) were used for the sample and the reference and a filter $(350 \mathrm{~nm}$ or $390 \mathrm{~nm}$ ) was inserted to eliminate the Rayleigh diffusion band and second order spectra. The references used were $[\mathrm{Eu}(\mathrm{L})]^{3+} 3 \times 10^{-5} \mathrm{M}$ in acetonitrile $\left(Q_{\mathrm{abs}}=23 \%\right.$, as measured with respect to a solution in water with known $\left.Q_{\text {abs }}=4.7 \%\right)$ and $[\mathrm{Tb}(\mathrm{L})]^{3+}\left(Q_{\mathrm{abs}}=25 \%\right) .{ }^{41}$ High resolution laser excited luminescence spectra have been measured at low temperature $(12 \mathrm{~K})$ using published procedures. ${ }^{42}$

\section{X-Ray crystallography}

White platelet crystals of the $\mathrm{Lu}^{\mathrm{III}}$ complex were obtained by slow vapour diffusion of $\mathrm{Et}_{2} \mathrm{O}$ into a $0.005 \mathrm{M}$ solution of the sample in $\mathrm{CH}_{3} \mathrm{CN}$. Diffraction data were collected at $143 \mathrm{~K}$ on a crystal $0.15 \times 0.10 \times 0.08 \mathrm{~mm}^{3}$ with the help of a mar345 imaging plate diffractometer. Data reduction was performed with the program marHKL (release 1.9.1) ${ }^{43}$ The structure was solved with ab-initio direct methods. ${ }^{44}$ The structure was refined using full-matrix least-squares on $F^{2}$ with all non-H atoms anisotropically defined. $\mathrm{H}$ atoms were placed in calculated positions using the "riding model" with $U_{\text {iso }}=0.08 \AA^{2}$. Due to the poor quality of data, several problems were encountered during the refinement, related to the disorder shown by three ethyl chains (C57, C58; C67, C68; C73, C74), by one $\mathrm{CF}_{3} \mathrm{SO}_{3}{ }^{-}$anion (S3, O20, O21, O22, C79, F7, F8, F9) and an external solvent molecule (O24, C84, C85, C86, C87). Reasonable parameters for such atoms were obtained by applying geometrical and rigid-body restraints. Structure refinement, molecular graphics and geometrical calculation have been carried with the SHELXTL software package (release 5.1). ${ }^{45}$ The co-ordination polyhedron (Fig. 3) was drawn with the help of the program PACHA. ${ }^{46}$ Experimental details are listed in Table 4.

CCDC reference number 166258.

See http://www.rsc.org/suppdata/dt/b1/b105513p/ for crystallographic data in CIF or other electronic format.

\section{Acknowledgements}

We gratefully acknowledge Ms Véronique Foiret for her technical assistance in luminescence measurements and Mr Daniel Baumann for infrared measurements. We thank Dr Juan Padilla of UAM-I, Mexico, for the EPR spectrum simulation. This work was supported through grants from the Swiss
Table 4 Experimental parameters for the crystal structure determination of $\left[\mathrm{Lu}\left(\mathrm{A}_{4} \mathrm{bL}^{4}\right)\left(\mathrm{H}_{2} \mathrm{O}\right)\right]\left(\mathrm{CF}_{3} \mathrm{SO}_{3}\right)_{3} \cdot 2 \mathrm{Et}_{2} \mathrm{O}$

\begin{tabular}{ll}
\hline Empirical formula & $\mathrm{C}_{87} \mathrm{H}_{138} \mathrm{~F}_{9} \mathrm{LuN}_{4} \mathrm{O}_{24} \mathrm{~S}_{3}$ \\
Formula weight & 2066.16 \\
Crystal system & Monoclinic \\
Space group & $P 2{ }_{1} / n$ \\
$a / \AA$ & $21.134(4)$ \\
$b / \AA$ & $23.251(5)$ \\
$c / \AA$ & $22.640(5)$ \\
$\beta / /^{\circ}$ & $106.71(3)$ \\
$V / \AA^{3}$ & $10655(4)$ \\
$Z$ & 4 \\
$\mu / \mathrm{mm}^{-1}$ & 1.066 \\
$T / \mathrm{K}$ & 143 \\
$F(000)$ & 4320 \\
Reflections measured & 36879 \\
Independent reflections & $13438\left(R_{\text {int }}=0.0732\right)$ \\
Observed reflections $[I>2 \sigma(I)]$ & 7843 \\
Final $R 1$, w $R 2[I>2 \sigma(I)]$ & $0.1082,0.2974$ \\
\hline
\end{tabular}

National Science Foundation and the National Institute of Nuclear Research of Mexico.

\section{References}

1 C. D. Gutsche, Calixarenes Revisited, Monographs in Supramolecular Chemistry, ed. J. F. Stoddart, Royal Society of Chemistry, Cambridge, 1998; L. Mandolini and R. Ungaro, Calixarenes in Action, Imperial College Press, London, 2000.

2 B. Valeur and I. Leray, Coord. Chem. Rev., 2000, 205, 3.

3 F. J. Steemers, W. Verboom, D. N. Reinhoudt, E. B. Vandertol and J. W. Verhoeven, J. Am. Chem. Soc., 1995, 117, 9408.

4 A. Casnati, C. Fischer, M. Guardigli, A. Isernia, I. Manet, N. Sabbatini and R. Ungaro, J. Chem. Soc., Perkin Trans. 2, 1996, 395.

5 M. P. O. Wolbers, F. C. J. M. Vanveggel, F. G. A. Peters, E. S. E. Vanbeelen, J. W. Hofstraat, F. J. Geurts and D. N. Reinhoudt, Chem. Eur. J., 1998, 4, 772.

6 R. Ludwig, Fresenius' J. Anal. Chem., 2000, 367, 103.

7 F. Arnaud-Neu, J. K. Browne, D. Byrne, D. J. Marrs, M. A. McKervey, P. O’Hagan, M.-J. Schwing-Weill and A. Walker, Chem. Eur. J., 1999, 5, 175.

8 J. F. Dozol, V. Lamare, N. Simon, R. Ungaro and A. Casnati, Calixarenes for Separations, ed. G. J. Lumetta, R. D. Rogers and A. Gopalan, American Chemical Society, Washington, DC, 2000, vol. 757, ch. 2, pp. 12-25.

9 M. Baaden, M. Burgard, C. Boehme and G. Wipff, Phys. Chem. Chem. Phys., 2001, 3, 1317.

10 J.-C. G. Bünzli, F. Besançon and F. Ihringer, Calixarenes for Separations, ed. G. J. Lumetta, R. D. Rogers and A. Gopalan, American Chemical Society, Washington, DC, 2000, vol. 757, ch. 14, pp. 179-194.

11 L. Le Saulnier, S. Varbanov, R. Scopelliti, M. Elhabiri and J.-C. G. Bünzli, J. Chem. Soc., Dalton Trans., 1999, 3919.

12 B. Lambert, V. Jacques, A. Shivanyuk, S. E. Matthews, A. Tunayar, M. Baaden, G. Wipff, V. Bohmer and J. F. Desreux, Inorg. Chem., 2000, 39, 2033.

13 A. Casnati, L. Baldini, N. Pelizzi, K. Rissanen, F. Ugozzoli and R. Ungaro, J. Chem. Soc., Dalton Trans., 2000, 3411.

14 M. R. Yaftian, M. Burgard, C. Wieser, C. B. Dieleman and D. Matt, Solv. Extr. Ion Exch., 1998, 16, 1131.

15 A. Varnek and G. Wipff, J. Phys. Chem., 1993, 97, 10840

16 M. F. Hazenkamp, G. Blasse, N. Sabbatini and R. Ungaro, Inorg. Chim. Acta, 1990, 172, 93.

17 N. Sabbatini, M. Guardigli, A. Mecati, V. Balzani, R. Ungaro, E. Ghidini, A. Casnati and A. Pochini, J. Chem. Soc., Chem. Commun., 1990, 878.

18 N. Sabbatini, M. Guardigli and J.-M. Lehn, Coord. Chem. Rev., 1993, 123, 201.

19 J. D. van Loon, J. F. Heida, W. Verboom and D. N. Reinhoudt, Recl. Trav. Chim. Pays-Bas, 1992, 111, 353.

20 J. B. Mann, J. Magn. Res., 1977, 25, 91

21 V. Bocchi, D. Foina, A. Pochini, R. Ungaro and G. D. Andreetti, Tetrahedron, 1982, 38, 373.

22 A. Arduini, E. Ghidini, A. Pochini, R. Ungaro, G. D. Andreetti, G. Calestani and F. Ugozzoli, J. Incl. Phenom. Mol. Recognit. Chem., 1988, 6, 119.

23 J. M. Moran, E. M. Georgiev, A. T. Yordanov, J. T. Mague and D. M. Roundhill, J. Org. Chem., 1994, 59, 5990. 
24 W. Schecher, MINEQL ${ }^{+}$, version 2.1, MD Environmental Research Software, Edgewater, New York, 1991.

25 C. D. Gutsche, Calixarenes, Monographs in Supramolecular Chemistry, ed. J. F. Stoddart, Royal Society of Chemistry, Cambridge, 1989.

26 L. J. Charbonnière, A. F. Williams, U. Frey, A. E. Merbach, P. Kamalaprija and O. Schaad, J. Am. Chem. Soc., 1997, 119, 2488.

27 M. E. M. Hamidi and J.-L. Pascal, Polyhedron, 1994, 13, 1787.

28 G. Muller, J.-C. G. Bünzli, K. J. Schenk, C. Piguet and G. Hopfgartner, Inorg. Chem., 2001, 40, 2642.

29 K. Nakamoto, Infrared and Raman Spectra of Inorganic and Coordination Compounds. Part A. Theory and Applications in Inorganic Chemistry, John Wiley Interscience Publications, New York, 1997.

30 R. D. Shannon, Acta Crystallogr., Sect. A, 1976, 32, 751.

31 J.-C. G. Bünzli, in Rare Earths, ed. R. Saez Puche and P. Caro, Editorial Complutense, Madrid, 1998, pp. 223-259.

32 L. J. Charbonnière, C. Balsiger, K. J. Schenk and J.-C. G. Bünzli, J. Chem. Soc., Dalton Trans., 1998, 505.

33 J. A. McMillan, Electron Paramagnetism, Reinhold Book Company, New York, 1967.

34 E. M. Stephens, in Lanthanide Probes in Life, Chemical and Earth Sciences. Theory and Practice, ed. J.-C. G. Bünzli and G. R. Choppin, Elsevier Science Publications B. V., Amsterdam, 1989, ch. 6 , pp. $181-217$
35 F. Neese, PhD Dissertation, University of Konstanz, Konstanz, Germany, 1994

36 R. S. Drago, Physical Methods for Chemists, Saunders College Publishing Co., New York, 1992.

37 M. Latva, H. Takalo, V. M. Mukkala, C. Matachescu, J.-C. Rodriguez-Ubis and J. Kankare, J. Lumin., 1997, 75, 149.

38 J.-C. G. Bünzli, in Lanthanide Probes in Life, Chemical and Earth Sciences. Theory and Practice, ed. J.-C. G. Bünzli and G. R. Choppin, Elsevier Science Publications B. V., Amsterdam, 1989, ch. 7, pp. 219-93.

39 A. Beeby, I. M. Clarkson, R. S. Dickins, S. Faulkner, D. Parker, L. Royle, A. S. de Sousa, J. A. G. Williams and M. Woods, J. Chem. Soc., Perkin Trans. 2, 1999, 493.

40 N. Sato and S. Shinkai, J. Chem. Soc, Perkin Trans. 2, 1993, 621

41 G. Zucchi, PhD Dissertation, University of Lausanne, 2000.

42 J.-C. G. Bünzli and A. Milicic-Tang, Inorg. Chim. Acta, 1996, 252, 221.

43 Z. Otwinowski and W. Minor, in Macromolecular Crystallography, Part A, ed. C. W. Carter Jr. and R. M. Sweet, Academic Press, New York, 1997, pp. 307-326.

44 G. M. Sheldrick, Acta Crystallogr. Sect. A, 1990, 46, 467.

45 Bruker AXS Inc., SHELXTL 5.1, Madison, Wisconsin, 1997.

46 M. Henry, PACHA Program, Partial Atomic CHarge Analysis, Université Louis Pasteur, Lab. Chimie Mol. de l'Etat Solide, F-67000 Strasbourg, France, 1993. 